\title{
Novel Mutations within PRSS1 Gene that Could Potentially Cause Hereditary Pancreatitis: Using Bioinformatics Approach
}

Mujahed I. Mustafa ${ }^{1 *}$, Abdelrahman H. Abdelmoneim ${ }^{1}$, Nafisa M. Elfadol $^{1}$, Soada A. Osman ${ }^{1}$, Tebyan A. Abdelhameed ${ }^{1}$, and Mohamed A. Hassan ${ }^{1,2}$

${ }^{1}$ Department of Biotechnology, Africa City of Technology, Khartoum, Sudan

${ }^{2}$ Department of Bioinformatics, DETAGEN Genetics Diagnostic Center, Kayseri, Turkey

* Corresponding author email: mujahedimustafa@gmail.com

Received: 19 July 2019 / Revised: 04 October 2019 / Accepted: 31 October 2019 / Published: 03 November 2019

\begin{abstract}
Hereditary pancreatitis (HP) is a rare heterogeneous disease with partial penetrance identified by frequent episodes of severe abdominal pain, often showing in young aged children. It is complicating by chronic pancreatitis, and high rate of pancreatic cancer (up to 40-50\%). The aim of this work was to classify the most deleterious mutation in PRSS1 gene and to predict their influence on the functional and structural level by a variety of bioinformatics analysis tools. The raw data of PRSS1 gene were recovered from SNP database, and further used to examine a deleterious effect using SIFT, PolyPhen2, PROVEAN, SNAP2, SNPs\&GO, PHD-SNP, PANTHER and P-Mut. The functional analysis predicted that two SNPs "rs1366278558 and rs767036052" have a deleterious effect at functional level. Additionally, we submitted them to I-mutant 3.0, and MUPro respectively to investigate their effect on structural level; the two tools revealed that; two mutations have a dramatic decrease of the protein stability, thus suggesting that the M1R and L4P mutations of PRSS1 gene could destabilize the amino acid interactions causing functional abnormalities of PRSS1 protein. The 3D structure of PRSS1 was predicted by RaptorX and modeled using UCSF Chimera to compare the differences between the native and the mutant amino acids. From the comparative analysis at the functional and structural level, these two SNPs "M1R and L4P" have a deleterious effect and thus could be used as diagnostic markers to predict HP. These findings can be used as a platform to develop large-scale studies in the future.
\end{abstract}

Keywords: Hereditary pancreatitis, Pancreatic Cancer, Bioinformatics Approach, Single-nucleotide polymorphisms, PRSS1.

\section{Introduction}

Hereditary pancreatitis (HP) is a rare heterogeneous disease with partial penetrance characterized by recurrent severe abdominal pain that manifest on juvenile age children. Progression to chronic pancreatitis is common with high rate of pancreatic malignancy (up to 40$50 \%$ ) with almost $80 \%$ penetrance and flexible fluency.[1-5] The first warning sign appears early before 10 years old, upon which they will be mainly complaining of pancreatic pain $(>70 \%)$. morphological variations as pancreatic calcifications are diagnosed at early age of 22-25 years. Exocrine and endocrine pancreatic deficiency happened in $34 \%$ and $26 \%$ of patients. $[6,7]$ The first family documented to have hereditary pancreatitis was described in 1952. [8, 9] after that about 100 families have been reported [4], which they were encountered by physicians in different countries [3, 10-16]. HP is a progressive inflammatory disease in which pancreatic secretory parenchyma is destroyed and replaced by fibrous tissue [17], as the disease progress it will eventually lead to malnutrition and diabetes.[18] Several studies show that; patients with HP have a significantly elevated risk of developing pancreatic cancer when compared with the overall people up to $40-50 \%[1,16,19$ 22], Also cigarette Smoking were found to rise the possibility factor for developing pancreatic malignancy in Patients suffering from Hereditary Pancreatitis.[23, 24] 
Novel Mutations within PRSS1 Gene that Could Potentially Cause Hereditary Pancreatitis: Using Bioinformatics Approach

Currently, there is no effective medical treatment for HP, but it can be managed by pancreatic enzyme replacement therapy along with analgesics to control the pain. In addition, endoscopic retrograde cholangiopancreatography (ERCP) and surgical intersections are reserved for complicated cases.[25-31]

HP has mainly been related with mutations in the serine protease 1 gene (PRSS1). It has been mapped to chromosome 7 q35.[5, 20] Among all genes that was mentioned in the literature to have associations with hereditary pancreatitis PRSS1 gene is the most reported one $[1,5-7,15,26,30$, 32-36], PRSS1 gene are found to encode human cationic trypsinogen. Furthermore Most high penetrance PRSS1 modifications will increase intra pancreatic trypsin activity. [37] Interestingly, mutations in PRSS1 gene may protect against the disease.[38, 39] In several studies (R122H), mutation in PRSS1 gene was strongly associated with hereditary pancreatitis $[6,25,32,40,41]$. The genetic makeup of the mutation in PRSS1 gene and full pathogenesis of by which it causes the disease is still unclear.[5] In vitro functional and characterization studies, is a highly demanding task in terms of workload, time and financial cost. For these reasons, computational analysis is an appropriate alternative that is more rapid and low-cost approach, which is why it has been used to study many types of inheritance diseases in the past years [42-44] to enrich our knowledge of the ways mutations could affect protein structure and function. The main objective of this work was to classify the most damaging SNPs that could be used as diagnostic markers. An extensive in silico approach using multiple software was used in this study, our result can be used as a platform to develop larger-scale studies in the future.

\section{Materials and Methods}

\subsection{Data mining}

The raw data of PRSS1 gene were retrieved from NCBI website by selecting the gene view from the main result page then downloading the resulted table in to an excel sheet[45], furthermore the protein reference sequence was collected from Uniprot[46]

\subsection{Functional Investigation of Damaging SNPs}

\subsubsection{SIFT}

Is the first in silico method for functional analysis, which calculates whether an amino acids alteration change protein function, or not. SIFT scores $<0.05$ are expected to be damaging altered amino acid, otherwise it considered to be tolerant.[47, 48] from the single protein tools we choose sift sequence, then we inserted our reference sequence with the original parameters unchanged and download the resulting values. The disadvantage about this tool is the inability to provide result for two sequence variations with the identical position in the same time.

\subsubsection{Polyphen-2}

It's a trained machine learning to predict the possible effect of amino acid replacement on protein function and structure, by calculating Position Specific Independent Count (PSIC) for each SNP at the time. It provides accurate predictions with three possible output whether probably damaging (values are more rapidly to one), possibly damaging or benign (values are varieties from zero to 0.95 .) $[49,50]$ we inserted the amino acid sequences after preparing it as the web site specification in to the batch query area on the site.

\subsubsection{PROVEAN}

It's very fast and accurate online in silico functional analysis tool that calculates whether specific amino acid replacement has an effect on the biological function of a protein depending on the alignment-based score. PROVEAN probability has two possibilities, deleterious or neutral with cutoff -2.5.[51] we choose (provean protein) choice from the web side and then inserted the reference sequence along with the amino acid variations without changing the parameter. Like SIFT, it can help the researcher identify mistakes in preparing the amino acid variations.

\subsubsection{SNAP2}

It is a trained functional analysis tool that differentiates between effect and neutral SNPs by taking a variety of features into validation. It 
consumes more time to work with the result than other tools and it got an accuracy of $83 \%$, with two expectations, effect (positive score) or neutral (negative score). But it still considered an important and substantial enhancement over other methods. [52]we directly run the prediction after entering the reference protein sequence.

\subsubsection{SNPs \& GO}

It is a trained machine learning based on the technique to precisely calculate the deleterious associated alterations from protein sequence. SNPs\&GO collects in unique framework information derived from protein sequence, evolutionary information, and function as coded in the Gene Ontology terms. SNPs\&GO performs other prediction methods (PHD-SNP and PANTHER) [53] we uploaded both the reference sequence and the amino acid variations then submit them and downloaded the result . The website provides friendly user environment with fast and reliable result.

\subsubsection{P-Mut}

It is a web-based tool for the explanation of SNPs alternates on proteins; it is characterized by fast and precise calculation. The mutations can be predicted to be either Neutral or disease causing. [54] we analyses the sequence and the variations through (analyzing mutations) link on the web side using PMut2017 predictor.

\subsection{Stability Investigation}

\subsubsection{I-Mutant 3.0}

It's a structural analysis online tool for the routine analysis of protein stability by considering the single-site alterations. Negative I-Mutant scores are expected to decrease the protein stability, otherwise (positive) it considered to increase it.[55] It is relatively easy to use website. We selected the (protein sequence) category that is related to (Prediction of protein stability changes upon single point mutations) then we inserted the reference sequence, the position and the residue and highlighted the (DDG value and binary classification method) before finally submitting these inputs.

\subsubsection{MUPro}

It is a structural analysis online tool for the calculation of protein stability variations upon arbitrarily SNPs. The value of the energy change is expected, and assurance mark between -1 and one for evaluating the assurance of the expectation is calculated. A score $<0$ means the mutant decreases the protein stability; conversely, a score $>0$ means the mutant increases the protein stability.[56]

\subsection{ConSurf server}

It is a web server offers evolutionary conservation summaries for proteins of known structure in the protein data bank. ConSurf spot the parallel amino acid sequences and run multi alignment methods. The conserved amino acid across species detects its position using specific algorisms.[57, 58]

\subsection{BioEdit}

It is a software package proposed to stream a distinct program that can run nearly any sequences operation as well as a few basic alignment investigations. [59] The FASTA format sequences of PRSS1 protein were retrieved from UniProt and used as an input to locate and determine if the SNPs are located at conserved sites or not. Through ClustalW choice in the accessory applications.

\subsection{GeneMANIA}

It is a method to identify protein function and gene - gene interactions; it integrates multiple genomics and proteomics data to create reliable information about the function of unknown proteins, although some time it fails to know the functions of some proteins.[60] we inserted the gene name then we download the relevant result into an excel sheet.

\subsection{D Clustering Analysis}

\subsubsection{Mutation3D}

It is a functional calculation and visualization online tool for investigating the threedimensional plan of amino acid alterations on protein models and structures. The input formats were the gene name and the SPNs of interest. [61] 
Novel Mutations within PRSS1 Gene that Could Potentially Cause Hereditary Pancreatitis: Using Bioinformatics Approach

\subsection{Biophysical Validation \& Visualization analysis}

\subsubsection{Project HOPE}

It is a webserver to search protein $3 \mathrm{D}$ structures by bringing together structural information from several sources such as UniProt database. The main aims for the submissions in Project HOPE are to analysis and confirm results that we had it earlier. [62] we upload the sequence without the identifications line then we defined the positions with the related amino acids. The advantage in using Project HOPE is the detailed information provided for each SNPs variation, but the main disadvantage would be the delay in the results that sometimes occurs for hours.

\subsubsection{Displaying Amino Acid Mutations}

For this task we used UCSF Chimera, It's for visualization and investigation of SNPs at the molecular level. Protein in Pdb format can be viewed by UCSF Chimera to scan the native and the mutant amino acids to observe the alterations that occur. [63] we study the structural changes mainly through (structure editing and rotamers ) tools in the chimera software .

\subsection{Variant Effect Predictor (VEP)}

The Ensembl Variant Effect Predictor software provides toolsets for an organized approach to annotate and aid prioritization of variants in both large-scale sequencing projects and smaller analysis studies.[64]

\section{Results and Discussion}

\subsection{Results}

Data related to the total number of SNPs in different regions of PRSS1 gene was retrieved from dbSNP database with the distribution of SNPs in coding and non-coding regions of PRSS1 gene (figure 1). Out of 911 SNPs there are 506 SNPs, contained 339 nsSNPs, 133 synonymous, 17 frame shit and 17 nonsense, with 26 in the $3^{\prime}$-UTR region and 11 in the $5^{\prime}$-UTR region (figure 2).

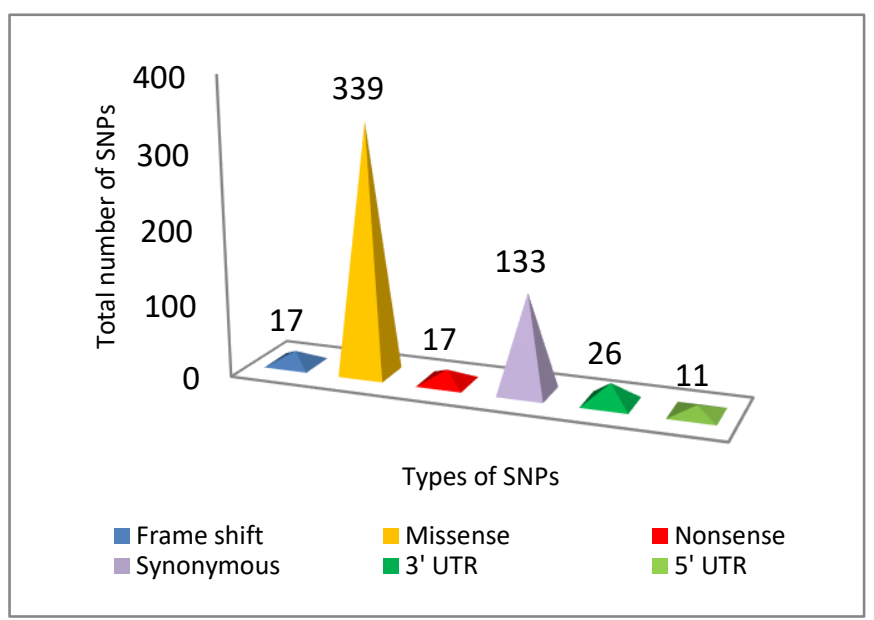

Figure 2: Graphic representation of PRSS1 gene workflow.

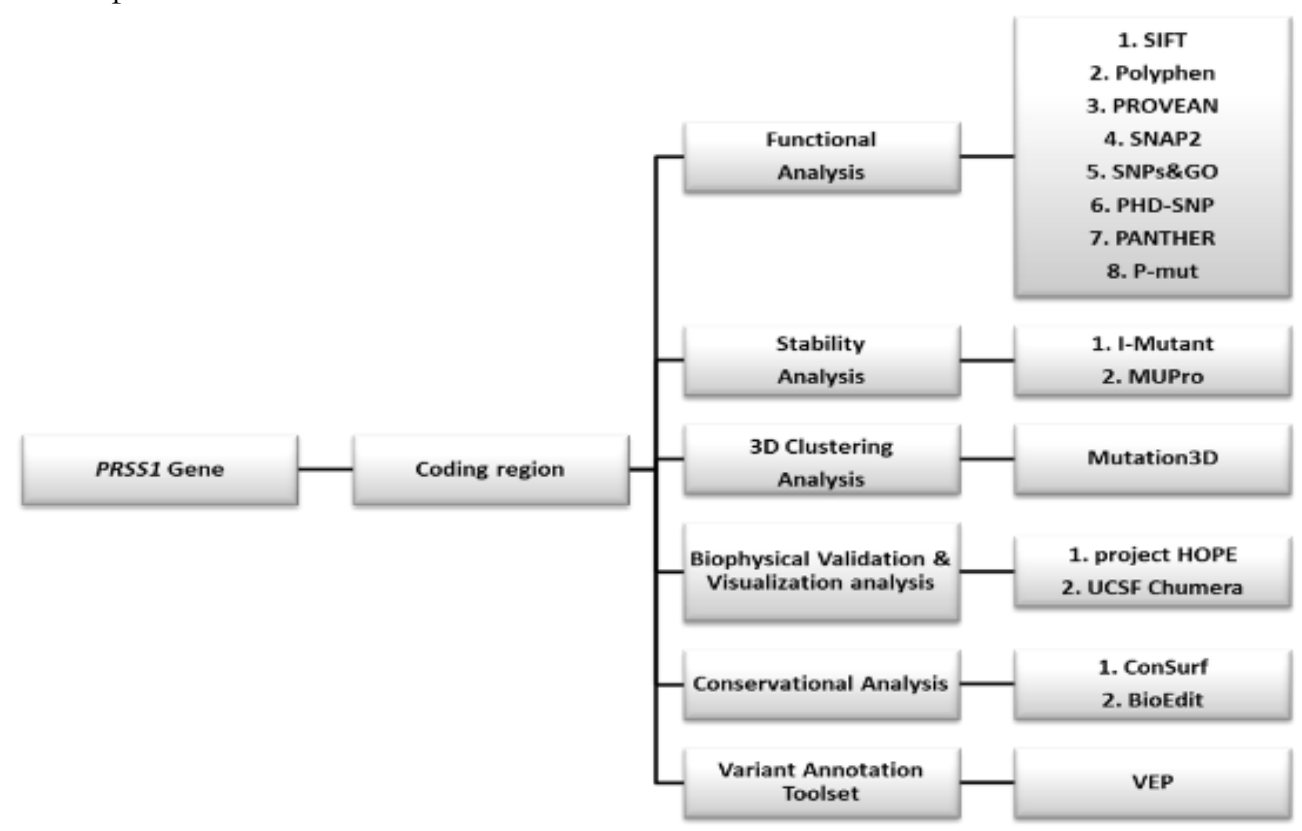

Figure 1: the distribution of SNPs in coding and non-coding regions of PRSS1 gene. 
These 339 nsSNPs were used to examine the deleterious effect on the associated protein. To identify the most deleterious nsSNPs, we toke the combined deleterious results from 8 functional tools, only the highly deleterious SNPs by SIFT,
PolyPhen, PROVEAN, SNAP2, SNPs\&GO, PHD-SNP, PANTHER and P-Mut, meet the criteria as illustrated in (Table 1,2 and 3). Remarkably, only two SNPs (M1R and L4P) give positive results with all the tools.

Table 1: Shows the affected SNPs that investigate by several online tools (*SUB: Substitutions (variants))

\begin{tabular}{|c|c|c|c|c|c|c|c|c|c|}
\hline \multirow[t]{2}{*}{ dbSNP rs\# } & \multirow[t]{2}{*}{ SUB } & \multicolumn{2}{|l|}{ SIFT } & \multicolumn{2}{|l|}{ Polyphen } & \multicolumn{2}{|c|}{ PROVEAN } & \multicolumn{2}{|l|}{ SNAP2 } \\
\hline & & prediction & Score & prediction & Score & Prediction & Score & prediction & Score \\
\hline rs 1366278558 & M1R & Damaging & 0 & probably damaging & 1 & Deleterious & -4.183 & effect & 51 \\
\hline rs780969708 & C30W & Damaging & 0 & probably damaging & 1 & Deleterious & -9.449 & effect & 66 \\
\hline rs769459903 & P36R & Damaging & 0 & probably damaging & 1 & Deleterious & -7.82 & effect & 59 \\
\hline rs138464021 & G49D & Damaging & 0 & probably damaging & 1 & Deleterious & -6.273 & effect & 90 \\
\hline- & G49V & Damaging & 0 & probably damaging & 1 & Deleterious & -8.061 & effect & 87 \\
\hline- & L52F & Damaging & 0 & probably damaging & 1 & Deleterious & -3.628 & effect & 32 \\
\hline rs149246646 & $\mathrm{I} 53 \mathrm{~N}$ & Damaging & 0 & probably damaging & 1 & Deleterious & -6.266 & effect & 68 \\
\hline rs 778570468 & W57G & Damaging & 0 & probably damaging & 1 & Deleterious & -11.76 & effect & 83 \\
\hline rs1338646513 & W57C & Damaging & 0 & probably damaging & 1 & Deleterious & -11.77 & effect & 63 \\
\hline rs 1192452565 & V58G & Damaging & 0 & probably damaging & 1 & Deleterious & -6.083 & effect & 73 \\
\hline rs370761165 & A61E & Damaging & 0 & probably damaging & 1 & Deleterious & -4.397 & effect & 80 \\
\hline rs372411481 & G83R & Damaging & 0 & probably damaging & 1 & Deleterious & -7.011 & effect & 40 \\
\hline- & G83W & Damaging & 0 & probably damaging & 1 & Deleterious & -7.169 & effect & 5 \\
\hline rs 1268805560 & H96Y & Damaging & 0 & probably damaging & 1 & Deleterious & -5.652 & effect & 72 \\
\hline rs1209409723 & H96Q & Damaging & 0 & probably damaging & 1 & Deleterious & -7.515 & effect & 78 \\
\hline rs1454816504 & Y99C & Damaging & 0 & probably damaging & 1 & Deleterious & -8.117 & effect & 72 \\
\hline rs 1323769980 & D107Y & Damaging & 0 & probably damaging & 1 & Deleterious & -8.448 & effect & 94 \\
\hline rs 1426710453 & L113H & Damaging & 0 & probably damaging & 1 & Deleterious & -6.567 & effect & 79 \\
\hline rs144403091 & V123M & Damaging & 0 & probably damaging & 1 & Deleterious & -2.664 & effect & 21 \\
\hline rs749518244 & L128Q & Damaging & 0 & probably damaging & 1 & Deleterious & -5.698 & effect & 49 \\
\hline- & L128P & Damaging & 0 & probably damaging & 1 & Deleterious & -6.649 & effect & 74 \\
\hline rs768673799 & P129H & Damaging & 0 & probably damaging & 1 & Deleterious & -8.254 & effect & 45 \\
\hline rs748208676 & $\mathrm{I} 141 \mathrm{~N}$ & Damaging & 0 & probably damaging & 1 & Deleterious & -6.392 & effect & 89 \\
\hline rs1164996242 & S142P & Damaging & 0 & probably damaging & 1 & Deleterious & -4.777 & effect & 86 \\
\hline rs 1164331073 & W144C & Damaging & 0 & probably damaging & 1 & Deleterious & -12.47 & effect & 80 \\
\hline rs 1221038304 & G145R & Damaging & 0 & probably damaging & 1 & Deleterious & -7.632 & effect & 91 \\
\hline rs 1172272446 & C160R & Damaging & 0 & probably damaging & 1 & Deleterious & -11.07 & effect & 28 \\
\hline rs778796800 & $\mathrm{C} 160 \mathrm{Y}$ & Damaging & 0 & probably damaging & 1 & Deleterious & -10.15 & effect & 22 \\
\hline- & $\mathrm{C} 160 \mathrm{~F}$ & Damaging & 0 & probably damaging & 1 & Deleterious & -10.15 & effect & 41 \\
\hline rs200973660 & $\mathrm{C} 171 \mathrm{Y}$ & Damaging & 0 & probably damaging & 1 & Deleterious & -10.21 & effect & 80 \\
\hline- & $\mathrm{C} 171 \mathrm{~S}$ & Damaging & 0 & probably damaging & 1 & Deleterious & -9.272 & effect & 78 \\
\hline rs 756821075 & $\mathrm{Y} 175 \mathrm{~N}$ & Damaging & 0 & probably damaging & 1 & Deleterious & -8.298 & effect & 75 \\
\hline- & $\mathrm{Y} 175 \mathrm{H}$ & Damaging & 0 & probably damaging & 1 & Deleterious & -4.616 & effect & 66 \\
\hline rs 1217657614 & D194V & Damaging & 0 & probably damaging & 1 & Deleterious & -8.36 & effect & 85 \\
\hline rs763907908 & C196G & Damaging & 0 & probably damaging & 1 & Deleterious & -11.15 & effect & 93 \\
\hline rs 1412477456 & G201R & Damaging & 0 & probably damaging & 1 & Deleterious & -7.194 & effect & 87 \\
\hline rs1288010897 & G201V & Damaging & 0 & probably damaging & 1 & Deleterious & -8.04 & effect & 83 \\
\hline rs 1289842951 & P203H & Damaging & 0 & probably damaging & 1 & Deleterious & -8.323 & effect & 65 \\
\hline rs747422004 & V205D & Damaging & 0 & probably damaging & 1 & Deleterious & -5.836 & effect & 81 \\
\hline rs1366495669 & S215P & Damaging & 0 & probably damaging & 1 & Deleterious & -4.618 & effect & 93 \\
\hline rs 1481112469 & C220W & Damaging & 0 & probably damaging & 1 & Deleterious & -10.13 & effect & 90 \\
\hline rs1164573795 & P226S & Damaging & 0 & probably damaging & 1 & Deleterious & -7.318 & effect & 63 \\
\hline rs1309672836 & Y229H & Damaging & 0 & probably damaging & 1 & Deleterious & -4.582 & effect & 85 \\
\hline
\end{tabular}


Novel Mutations within PRSS1 Gene that Could Potentially Cause Hereditary Pancreatitis: Using Bioinformatics Approach

Table 2: List of SNPs analyzed for disease association by three online servers (*RI: Reliability Index)

\begin{tabular}{|c|c|c|c|c|c|c|c|c|c|c|}
\hline dbSNP rs\# & Mutation & $\begin{array}{c}\text { PHD- } \\
\text { SNP } \\
\text { Prediction } \\
\end{array}$ & RI & Probability & $\begin{array}{l}\text { SNP \&Go } \\
\text { Prediction }\end{array}$ & RI & Probability & $\begin{array}{l}\text { PANTHER } \\
\text { Prediction }\end{array}$ & RI & Probability \\
\hline rs1366278558 & M1R & Disease & 0 & 0.514 & Disease & 3 & 0.668 & Disease & 9 & 0.95 \\
\hline rs780969708 & C30W & Disease & 6 & 0.825 & Disease & 7 & 0.848 & Disease & 10 & 0.99 \\
\hline rs769459903 & P36R & Disease & 4 & 0.708 & Disease & 1 & 0.558 & Disease & 5 & 0.734 \\
\hline rs138464021 & G49D & Disease & 8 & 0.917 & Disease & 7 & 0.862 & Disease & 8 & 0.88 \\
\hline- & G49V & Disease & 8 & 0.913 & Disease & 7 & 0.852 & Disease & 8 & 0.902 \\
\hline- & $\mathrm{L} 52 \mathrm{~F}$ & Disease & 7 & 0.841 & Disease & 6 & 0.783 & Disease & 9 & 0.954 \\
\hline rs149246646 & $\mathrm{I} 53 \mathrm{~N}$ & Disease & 8 & 0.888 & Disease & 7 & 0.844 & Disease & 8 & 0.891 \\
\hline rs778570468 & W57G & Disease & 8 & 0.897 & Disease & 6 & 0.787 & Disease & 10 & 0.98 \\
\hline rs 1338646513 & W57C & Disease & 9 & 0.942 & Disease & 7 & 0.849 & Disease & 10 & 0.993 \\
\hline rs1192452565 & V58G & Disease & 6 & 0.818 & Disease & 4 & 0.695 & Disease & 7 & 0.848 \\
\hline rs370761165 & A61E & Disease & 8 & 0.891 & Disease & 5 & 0.762 & Disease & 6 & 0.779 \\
\hline rs372411481 & G83R & Disease & 3 & 0.67 & Disease & 3 & 0.667 & Disease & 4 & 0.715 \\
\hline- & G83W & Disease & 5 & 0.756 & Disease & 4 & 0.687 & Disease & 9 & 0.952 \\
\hline rs1268805560 & H96Y & Disease & 8 & 0.879 & Disease & 5 & 0.741 & Disease & 4 & 0.695 \\
\hline rs1209409723 & H96Q & Disease & 7 & 0.867 & Disease & 5 & 0.728 & Disease & 3 & 0.673 \\
\hline rs 1454816504 & Y99C & Disease & 7 & 0.867 & Disease & 5 & 0.756 & Disease & 9 & 0.927 \\
\hline rs1323769980 & D107Y & Disease & 9 & 0.933 & Disease & 7 & 0.829 & Disease & 9 & 0.973 \\
\hline rs 1426710453 & L113H & Disease & 8 & 0.905 & Disease & 5 & 0.765 & Disease & 9 & 0.935 \\
\hline rs144403091 & V123M & Disease & 0 & 0.511 & Disease & 0 & 0.507 & Disease & 4 & 0.681 \\
\hline rs749518244 & L128Q & Disease & 5 & 0.753 & Disease & 4 & 0.7 & Disease & 7 & 0.869 \\
\hline- & L128P & Disease & 5 & 0.765 & Disease & 4 & 0.7 & Disease & 8 & 0.902 \\
\hline rs768673799 & P129H & Disease & 3 & 0.66 & Disease & 1 & 0.545 & Disease & 7 & 0.845 \\
\hline rs748208676 & $\mathrm{I} 141 \mathrm{~N}$ & Disease & 6 & 0.794 & Disease & 6 & 0.823 & Disease & 7 & 0.87 \\
\hline rs1164996242 & $\mathrm{S} 142 \mathrm{P}$ & Disease & 6 & 0.812 & Disease & 7 & 0.853 & Disease & 6 & 0.817 \\
\hline rs1164331073 & W144C & Disease & 9 & 0.929 & Disease & 6 & 0.805 & Disease & 8 & 0.918 \\
\hline rs1221038304 & G145R & Disease & 7 & 0.866 & Disease & 6 & 0.812 & Disease & 9 & 0.966 \\
\hline rs 1172272446 & C160R & Disease & 5 & 0.757 & Disease & 8 & 0.876 & Disease & 10 & 0.987 \\
\hline rs778796800 & C160Y & Disease & 3 & 0.674 & Disease & 7 & 0.834 & Disease & 10 & 0.992 \\
\hline- & $\mathrm{C} 160 \mathrm{~F}$ & Disease & 5 & 0.76 & Disease & 7 & 0.866 & Disease & 10 & 0.99 \\
\hline rs200973660 & $\mathrm{C} 171 \mathrm{Y}$ & Disease & 8 & 0.925 & Disease & 7 & 0.827 & Disease & 10 & 1 \\
\hline- & $\mathrm{C} 171 \mathrm{~S}$ & Disease & 8 & 0.895 & Disease & 5 & 0.772 & Disease & 10 & 1 \\
\hline rs756821075 & $\mathrm{Y} 175 \mathrm{~N}$ & Disease & 7 & 0.835 & Disease & 4 & 0.698 & Disease & 7 & 0.873 \\
\hline- & $\mathrm{Y} 175 \mathrm{H}$ & Disease & 3 & 0.661 & Disease & 2 & 0.589 & Disease & 6 & 0.806 \\
\hline rs 1217657614 & D194V & Disease & 8 & 0.904 & Disease & 7 & 0.872 & Disease & 8 & 0.898 \\
\hline rs763907908 & C196G & Disease & 6 & 0.816 & Disease & 5 & 0.743 & Disease & 10 & 0.999 \\
\hline rs 1412477456 & G201R & Disease & 8 & 0.882 & Disease & 7 & 0.839 & Disease & 7 & 0.849 \\
\hline rs1288010897 & $\mathrm{G} 201 \mathrm{~V}$ & Disease & 8 & 0.906 & Disease & 7 & 0.855 & Disease & 7 & 0.84 \\
\hline rs1289842951 & $\mathrm{P} 203 \mathrm{H}$ & Disease & 7 & 0.835 & Disease & 4 & 0.701 & Disease & 10 & 0.979 \\
\hline rs747422004 & V205D & Disease & 7 & 0.831 & Disease & 6 & 0.775 & Disease & 8 & 0.903 \\
\hline rs1366495669 & $\mathrm{S} 215 \mathrm{P}$ & Disease & 8 & 0.878 & Disease & 7 & 0.827 & Disease & 6 & 0.804 \\
\hline rs 1481112469 & C220W & Disease & 9 & 0.928 & Disease & 7 & 0.855 & Disease & 9 & 0.967 \\
\hline rs1164573795 & P226S & Disease & 7 & 0.871 & Disease & 6 & 0.787 & Disease & 9 & 0.933 \\
\hline rs 1309672836 & Y229H & Disease & 6 & 0.795 & Disease & 1 & 0.573 & Disease & 5 & 0.742 \\
\hline
\end{tabular}


Table 3: Show a List of SNPs investigated by P-Mut

\begin{tabular}{lccc}
\hline dbSNP rs\# & Amino Acid change & P-mut Prediction & P-mut Score \\
\hline rs1366278558 & M1R & Decrease & $0.78(88 \%)$ \\
rs767036052 & L4P & Decrease & $0.70(86 \%)$ \\
\hline
\end{tabular}

Table 4: Structural Investigation predicted by using I-Mutant v3.0 and MUPro

\begin{tabular}{|c|c|c|c|c|c|c|}
\hline dbSNP rs\# & $\begin{array}{l}\text { Amino } \\
\text { Acid } \\
\text { change }\end{array}$ & $\begin{array}{c}\text { SVM2 } \\
\text { Prediction } \\
\text { Effect }\end{array}$ & RI & $\begin{array}{c}\text { DDG Value } \\
\text { Prediction }\end{array}$ & $\begin{array}{c}\text { MUPro } \\
\text { Prediction }\end{array}$ & $\begin{array}{c}\text { MUPro } \\
\text { Score }\end{array}$ \\
\hline rs1366278558 & M1R & Decrease & 1 & -0.62 & Decrease & -1.0183 \\
\hline rs767036052 & L4P & Decrease & 8 & -1.66 & Decrease & -1.6239 \\
\hline
\end{tabular}

Further additional analysis were held for only these 2 SNPs.we submitted them to I-mutant 3.0, and MUPro respectively to investigate their effect on the structural level; the two tools revealed that, there is a dramatic decrease in the protein stability, thus suggesting that the M1R and L4P mutations of PRSS1 could destabilize the amino acid interactions causing functional abnormalities of PRSS1 protein. (Table 4)

\subsection{Discussion}

Two mutations were predicted to have a potential major impact on the structure and function of the PRSS1 protein by using different computational analysis tools (Figure 2). The approaches used were grounded on different characteristics and limitations that unmask the pathogenicity and deliver evidences about the influence of each mutation. In the past years in silico analysis has been done for several inherited diseases and tumor associated genes along with other disorders. [43, 65, 66] in this study we used computational in silico analysis of PRSS1 gene to study nsSNP effect on the PRSS1 protein that could lead to the development of Hereditary Pancreatitis. These SNPs were submitted to SIFT, PolyPhen, PROVEAN, and SNAP2 sever; we found 141 SNPs to be damaging by SIFT. In PolyPhen2, the results showed that 170 SNPs were found to be damaging (54 possibly damaging and 116 probably damaging showed deleterious). In PROVEAN server our result showed that 203 SNPs were predicted to be deleterious. While in SNAP2 server the result showed that 172 SNPs were predicted to be deleterious. The alterations in calculation abilities and result are likely duo to the fact that every prediction algorithm uses different sets of sequences and alignments. we submitted the four positive combined SNPs results from SIFT, PolyPhen-2, PROVEAN and SNAP2 (Table 1) to be analyzed further by disease related softwares: SNPs \& GO, PHD-SNP, PANTHER(Table2), P-Mut and MUPro servers. There was (85, 95 and 90) SNPs founded to be disease related by SNPs \& GO, PHD-SNP and PANTHER servers respectively. While MUPro servers revealed different and unique results of only 2 disease related SNPs as shown in (Table3). We selected only the four positive combined results (disease-causing SNPs). (Figure 3) illustrate the relation between these soft wares. Additionally, we performed analysis by Mutation3D; our result shows that: (L4P) located in a domain, which indicates its vital significance (Figure 4).

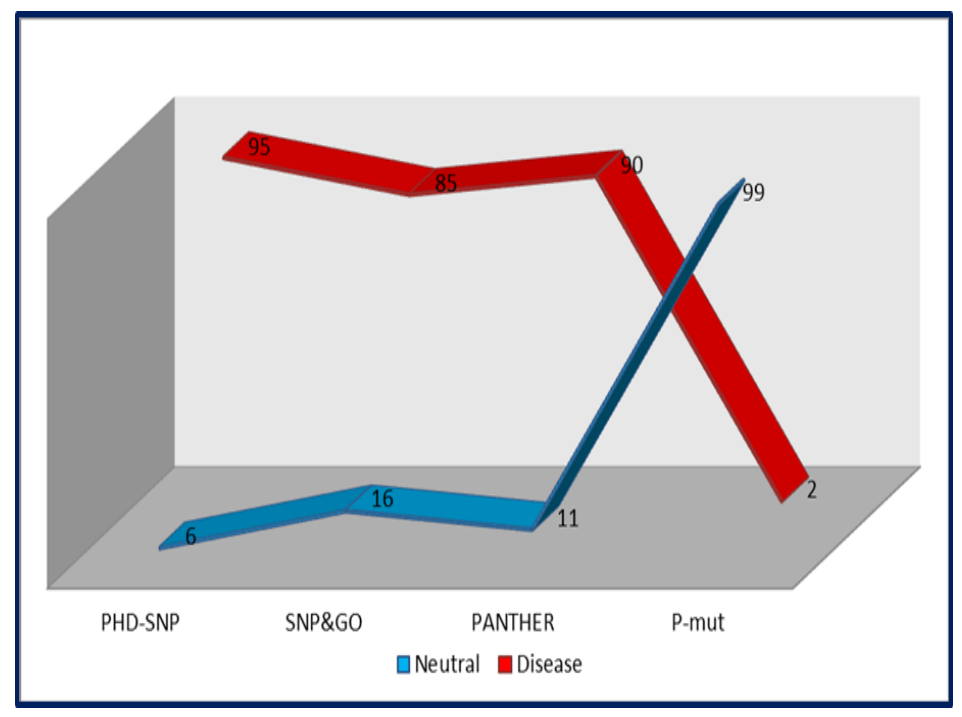

Figure 3: Shows Illustration of damaging mutations predicted by numerous of tools. 
Novel Mutations within PRSS1 Gene that Could Potentially Cause Hereditary Pancreatitis: Using Bioinformatics Approach

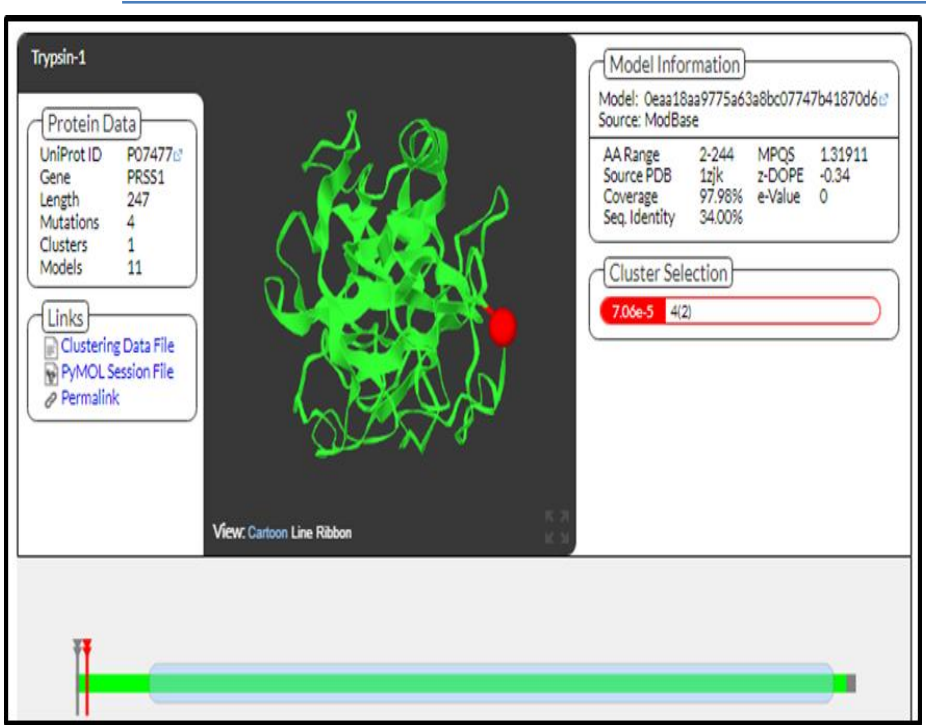

Figure 4: Screenshot for (L4P) shows highpossibility SNP in its domain.

The 3D protein structure analysis enables mapping of amino acid substitutions and, therefore, RaptorX was used to make a 3D structure model for PRSS1 protein (Figure 5).

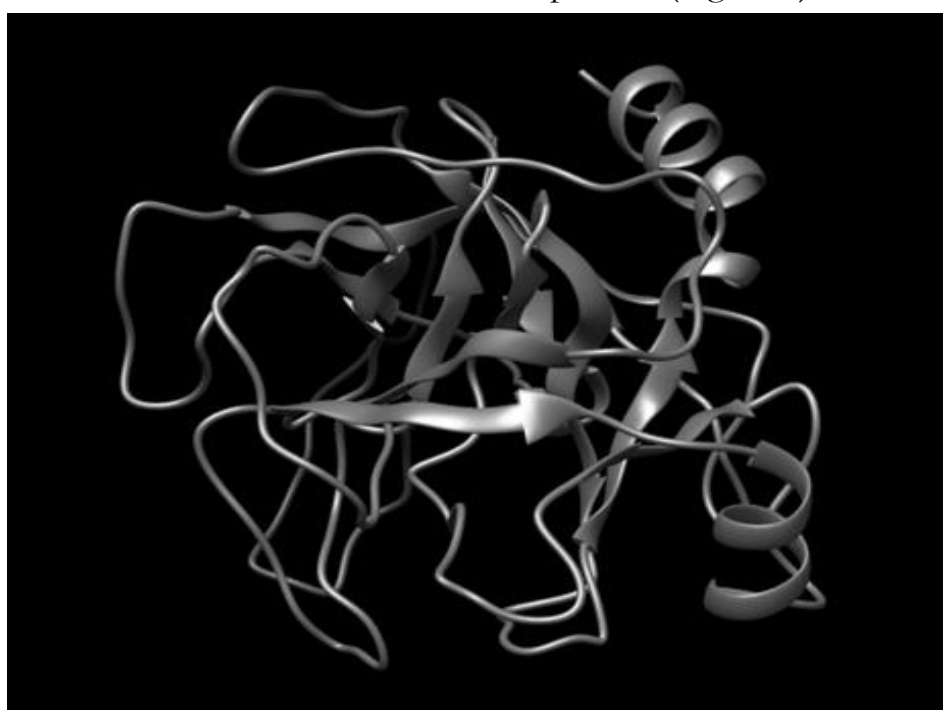

Figure 5: The 3D structure of PRSS1 protein model was generated by using RaptorX.

To supports and matches the results acquired from different computational tools, we used UCSF Chimera. (Figure 6-7) shows the differences between native and mutant amino acids illustrated here in the green and red boxes. The schematic structures of the native amino acids are in the left side and the mutant ones are in the right side. The backbone, which is the same for each amino acid, is colored red and the side chain, unique for each amino acid is colored black, the 3D wide type residues colored green and mutant ones colored red, while the protein is colored dark gray. Project HOPE server was used to submit the two most deleterious nsSNPs (M1R) and (L4P). (rs1366278558): (M1R): Methionine changed to Arginine at position 1. As showed in (Figure 6) this may decrease the protein stability which disrupts the amino acid interactions. (rs767036052):(L4P): Leucine residue changed to Proline at position 4. As showed in (Figure 7) the altered remain is smaller; this may cause loss of interactions.

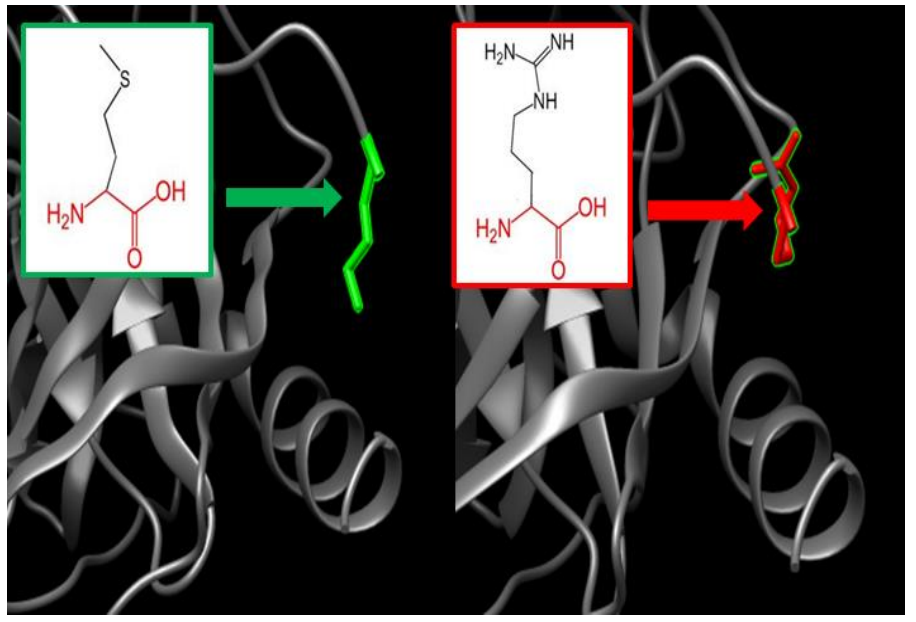

Figure 6: Shows Methionine changes to Arginine at position 1.

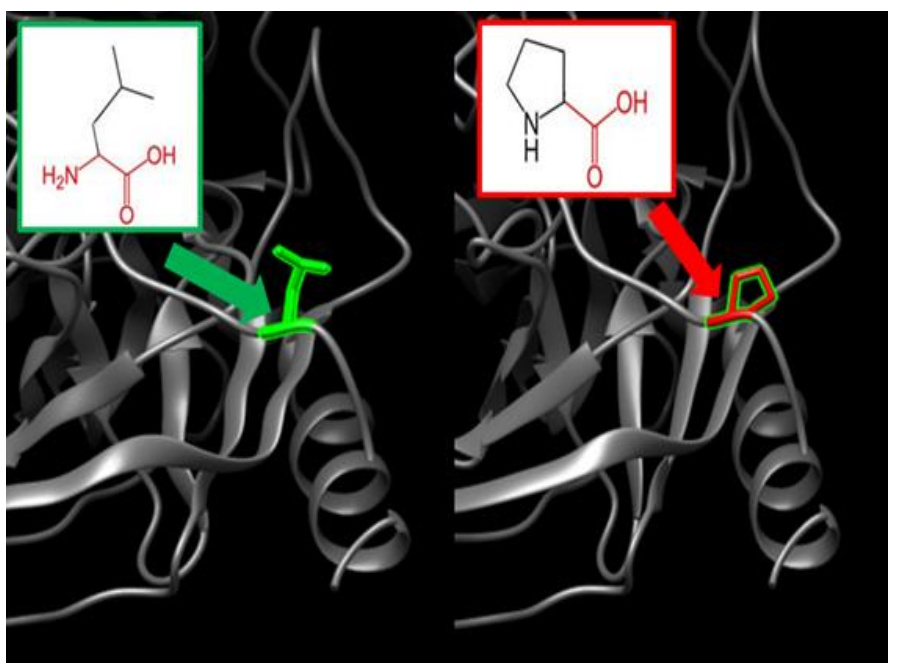

Figure 7: Shows Leucine changes to Proline at position 4.

We also used ConSurf to flag the SNPs that are sited at highly conserved amino acid positions, which has a tendency be more damaging than SNPs that are sited at non- preserved positions. Our ConSurf analysis unmasked that (L4P) mutation was found in highly conserved site and expected to have a high influence on PRSS1 
protein structure and function as illustrated in (Figure 8). To confirm our findings on (M1R \& L4P) mutations, we used BioEdit (version 7.2.5) where Alignment of 10 amino acid arrangements of PRSS1 confirm their conservation and hence significance as evident in (Figure 9).

GeneMANIA revealed that PRSS1 has many vital functions: blood microparticle, cobalamin metabolic process, extracellular matrix organization, extracellular structure organization, serine hydrolase activity, serine-type endopeptidase activity, serine-type peptidase activity. The associated genes contribute to accomplish similar function were demonstrated by GeneMANIA. on (Figure 10) and (Table 5-6). The VEP annotates variants using a wide range of reference data. That include transcripts, regulatory regions, and frequencies from previously observed variants, citations, clinical significance information, and predictions of biophysical consequences of variants, and that what makes VEP give accurate results [64].

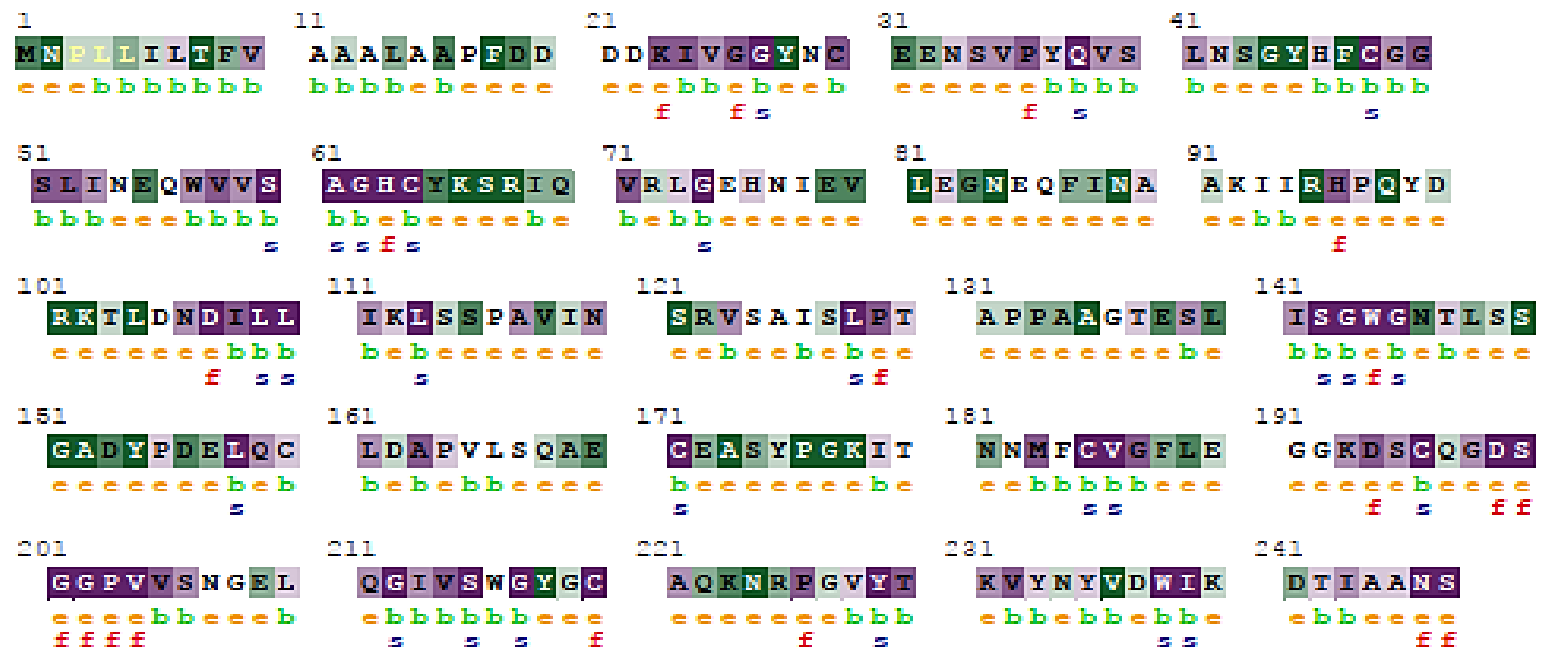

\footnotetext{
The conservation scale:

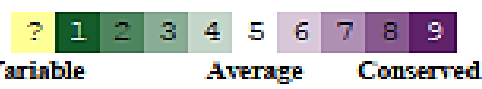

Figure 8: Shows the conserved amino acids across species in PRSS1 protein were determined using Consurf. (e) An exposed residues according to the neural-network algorithm via an orange letter. $(b)$ Residues predicted to be buried are demonstrated via a green letter. (f) A predicted functional residues (highly conserved and exposed) are indicated with a red letter. (s) A predicted structural residues (highly conserved and buried) that are demonstrated with a blue letter. (?) Insufficient data- the calculation for this site was performed on less than $10 \%$ of the sequences are demonstrated via a yellow letter.

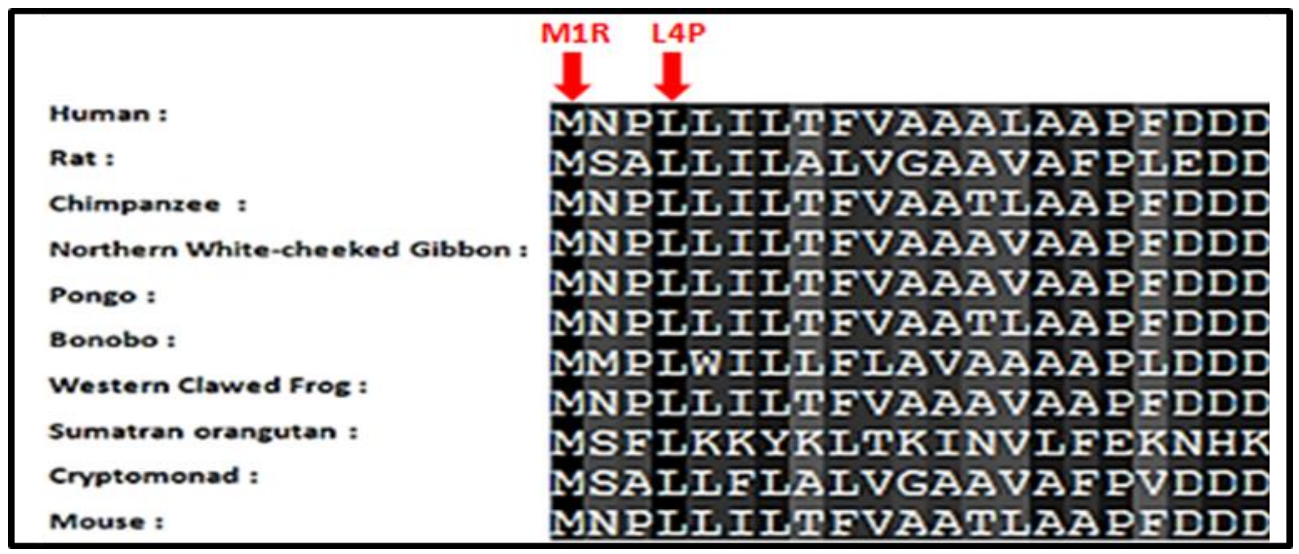

Figure 9: Alignment of 10 amino acid sequences of PRSS1 demonstrating that the residues predicted to be mutated (indicated by red arrows) are evolutionarily conserved across species. 


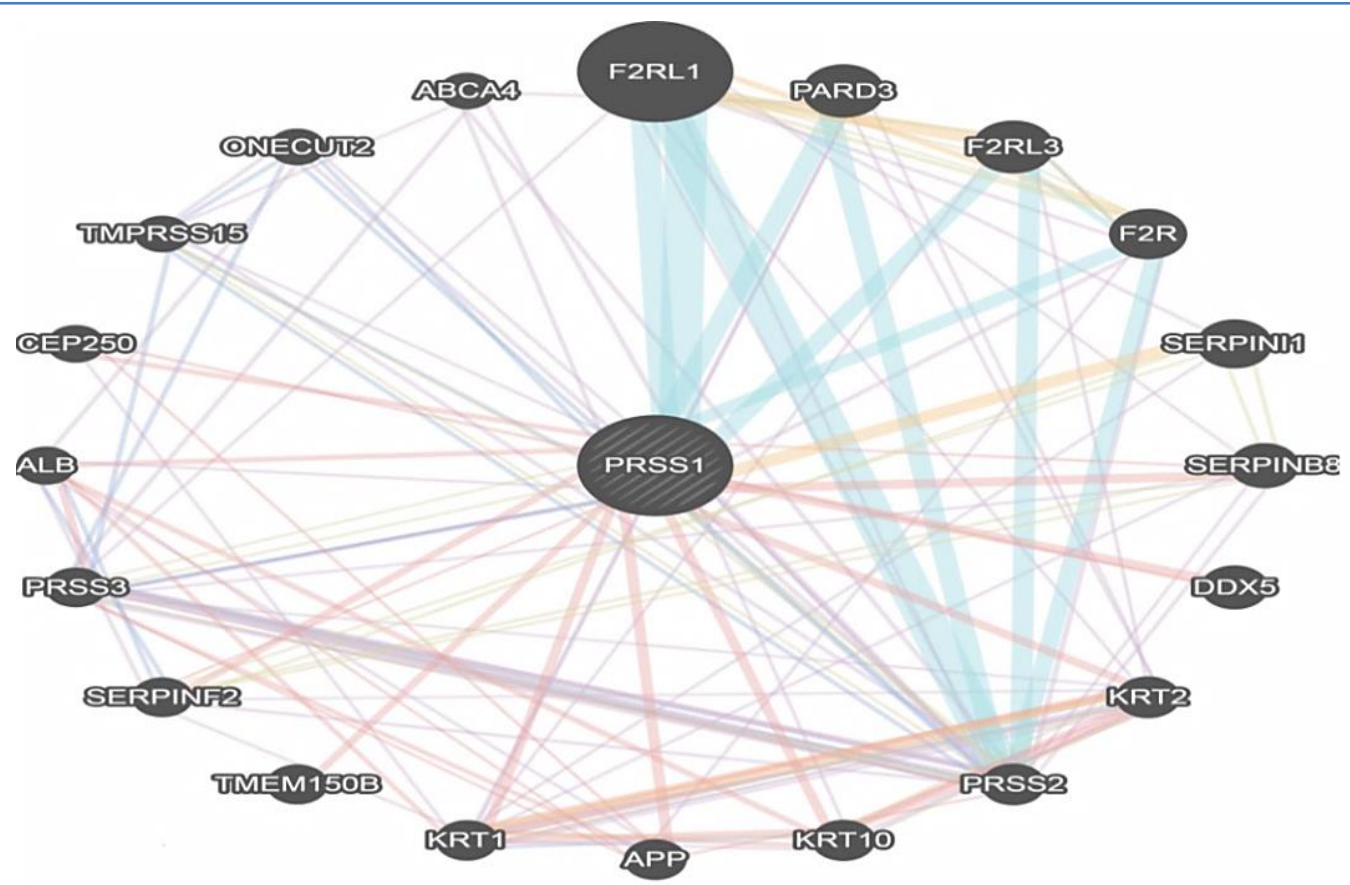

\section{Networks}

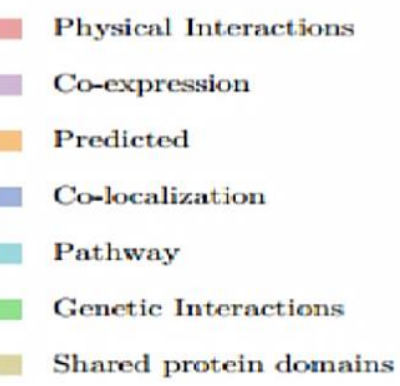

Figure 10: Shows the relations between PRSS1 and its associated genes.

Table 5: PRSS1 gene functions and its appearance in network and genome

\begin{tabular}{lccc}
\hline & & Genes in & Genes in \\
Function & FDR & network & genome \\
\hline serine-type endopeptidase inhibitor activity & 0.001356361 & 4 & 44 \\
renal system process involved in regulation of systemic arterial blood pressure & 0.001356361 & 3 & 13 \\
regulation of hemostasis & 0.001356361 & 4 & 54 \\
regulation of coagulation & 0.001356361 & 4 & 56 \\
regulation of blood coagulation & 0.001356361 & 4 & 54 \\
regulation of wound healing & 0.003496886 & 4 & 74 \\
platelet activation & 0.006856052 & 5 & 211 \\
endopeptidase inhibitor activity & 0.007599469 & 4 & 99 \\
endopeptidase regulator activity & 0.007599469 & 4 & 102 \\
peptidase inhibitor activity & 0.007599469 & 4 & 101 \\
blood microparticle & 0.008676071 & 4 & 108 \\
regulation of endopeptidase activity & 0.009340491 & 5 & 251 \\
regulation of peptidase activity & 0.009856636 & 5 & 258 \\
peptidase regulator activity & 0.013382385 & 4 & 128 \\
renal system process & 0.013666888 & 3 & 45 \\
endocrine process & 0.013666888 & 3 & 42 \\
negative regulation of endopeptidase activity & 0.013666888 & 4 & 140 \\
regulation of blood vessel size & 0.013666888 & 3 & 44 \\
regulation of tube size & 0.013666888 & 3 & 44 \\
negative regulation of peptidase activity & 0.013666888 & 4 & 142 \\
regulation of systemic arterial blood pressure & 0.013666888 & 3 \\
& & 43 \\
\hline
\end{tabular}


Mustafa et al., Int. Ann. Sci.; Vol. 8, Issue 1, pp: 96-113, 2020

platelet alpha granule lumen

vascular process in circulatory system

platelet alpha granule

secretory granule lumen

serine-type endopeptidase activity

killing of cells of other organism

exocytosis

disruption of cells of other organism

glomerular filtration

renal filtration

vesicle lumen

enzyme inhibitor activity

protein kinase C-activating G-protein coupled receptor signaling pathway

cytoplasmic membrane-bounded vesicle lumen

positive regulation of collagen metabolic process

positive regulation of collagen biosynthetic process

regulation of blood pressure

platelet degranulation

positive regulation of ERK1 and ERK2 cascade

negative regulation of multicellular organismal process

positive regulation of coagulation

negative regulation of hydrolase activity

collagen metabolic process

positive regulation of hemostasis

positive regulation of blood coagulation

positive regulation of multicellular organismal metabolic process

multicellular organismal macromolecule metabolic process

regulation of endocrine process

regulation of collagen biosynthetic process

tissue homeostasis

zymogen activation

regulation of collagen metabolic process

multicellular organismal metabolic process

positive regulation of release of sequestered calcium ion into cytosol

serine-type peptidase activity

serine hydrolase activity

cellular metal ion homeostasis

positive regulation of Ras protein signal transduction

collagen biosynthetic process

multicellular organismal homeostasis

regulation of multicellular organismal metabolic process

positive regulation of small GTPase mediated signal transduction

cobalamin metabolic process

fibrinolysis

cellular cation homeostasis

regulation of ERK1 and ERK2 cascade

metal ion homeostasis

cellular ion homeostasis

extracellular matrix organization

extracellular structure organization

ERK1 and ERK2 cascade

positive regulation of calcium ion transport into cytosol

positive regulation of cytosolic calcium ion concentration

\begin{tabular}{|c|c|c|}
\hline 0.01586832 & 3 & 48 \\
\hline 0.028313203 & 3 & 59 \\
\hline 0.029997483 & 3 & 61 \\
\hline 0.030241005 & 3 & 62 \\
\hline 0.033116705 & 3 & 67 \\
\hline 0.033116705 & 2 & 10 \\
\hline 0.033116705 & 4 & 191 \\
\hline 0.033116705 & 2 & 10 \\
\hline 0.037840129 & 2 & 11 \\
\hline 0.037840129 & 2 & 11 \\
\hline 0.040192639 & 3 & 76 \\
\hline 0.040192639 & 4 & 214 \\
\hline 0.040192639 & 2 & 12 \\
\hline 0.040192639 & 3 & 76 \\
\hline 0.044298773 & 2 & 13 \\
\hline 0.044298773 & 2 & 13 \\
\hline 0.044298773 & 3 & 81 \\
\hline 0.044771122 & 3 & 82 \\
\hline 0.04525757 & 3 & 83 \\
\hline 0.045315882 & 4 & 230 \\
\hline 0.048108433 & 2 & 15 \\
\hline 0.048108433 & 4 & 242 \\
\hline 0.048108433 & 3 & 87 \\
\hline 0.048108433 & 2 & 15 \\
\hline 0.048108433 & 2 & 15 \\
\hline 0.048108433 & 2 & 15 \\
\hline 0.049591958 & 3 & 91 \\
\hline 0.051022071 & 2 & 16 \\
\hline 0.051022071 & 2 & 16 \\
\hline 0.051393559 & 3 & 94 \\
\hline 0.052534202 & 3 & 97 \\
\hline 0.052534202 & 2 & 17 \\
\hline 0.052534202 & 3 & 97 \\
\hline 0.052534202 & 2 & 17 \\
\hline 0.052961891 & 3 & 98 \\
\hline 0.055058507 & 3 & 101 \\
\hline 0.055058507 & 4 & 264 \\
\hline 0.055058507 & 2 & 18 \\
\hline 0.057743853 & 2 & 19 \\
\hline 0.057743853 & 3 & 105 \\
\hline 0.057743853 & 2 & 19 \\
\hline 0.057743853 & 2 & 19 \\
\hline 0.0619817 & 2 & 20 \\
\hline 0.0619817 & 2 & 20 \\
\hline 0.063339568 & 4 & 284 \\
\hline 0.063981924 & 3 & 111 \\
\hline 0.064852029 & 4 & 288 \\
\hline 0.066330871 & 4 & 292 \\
\hline 0.066330871 & 4 & 292 \\
\hline 0.066330871 & 4 & 293 \\
\hline 0.07491573 & 3 & 120 \\
\hline 0.094036985 & 2 & 26 \\
\hline 0.094313684 & 3 & 131 \\
\hline
\end{tabular}

*FDR: false discovery rate is greater than or equal to the probability that this is a false positive

Table 6: The gene co-expression, shared domain, and interaction with PRSS1gene network

\begin{tabular}{cccl}
\hline Gene 1 & Gene 2 & Weight & Network group \\
\hline F2R & PRSS1 & 0.025958601 & Co-expression \\
PRSS2 & PRSS1 & 0.03579626 & Co-expression \\
PRSS2 & $F 2 R$ & 0.025450852 & Co-expression \\
KRT1 & KRT2 & 0.021397633 & Co-expression \\
PRSS3 & PRSS1 & 0.033738803 & Co-expression \\
\hline
\end{tabular}


Novel Mutations within PRSS1 Gene that Could Potentially Cause Hereditary Pancreatitis: Using Bioinformatics Approach

\begin{tabular}{|c|c|c|c|}
\hline PRSS3 & PRSS2 & 0.033134628 & Co-expression \\
\hline$A B C A 4$ & PRSS1 & 0.020958284 & Co-expression \\
\hline$A B C A 4$ & PRSS2 & 0.021833802 & Co-expression \\
\hline$A B C A 4$ & PRSS3 & 0.020297663 & Co-expression \\
\hline$F 2 R$ & $F 2 R L 1$ & 0.01723061 & Co-expression \\
\hline SERPINF2 & $K R T 1$ & 0.005162225 & Co-expression \\
\hline PRSS3 & PRSS2 & 0.030308522 & Co-expression \\
\hline$A B C A 4$ & PARD3 & 0.018756393 & Co-expression \\
\hline SERPINII & $F 2 R L 1$ & 0.018079963 & Co-expression \\
\hline PRSS2 & PRSS1 & 0.010663025 & Co-expression \\
\hline KRT10 & PRSS1 & 0.004751287 & Co-expression \\
\hline$K R T 1$ & $K R T 2$ & 0.017388888 & Co-expression \\
\hline PRSS3 & PRSS2 & 0.016354393 & Co-expression \\
\hline$A L B$ & PRSS1 & 0.00978991 & Co-expression \\
\hline TMPRSS15 & PRSS1 & 0.009836646 & Co-expression \\
\hline TMPRSS15 & PRSS2 & 0.02349308 & Co-expression \\
\hline ONECUT2 & PRSS1 & 0.011885054 & Co-expression \\
\hline ONECUT2 & PRSS2 & 0.026482629 & Co-expression \\
\hline ONECUT2 & $A L B$ & 0.023143126 & Co-expression \\
\hline ONECUT2 & TMPRSS15 & 0.023315145 & Co-expression \\
\hline$K R T 2$ & PARD3 & 0.00407993 & Co-expression \\
\hline$K R T 2$ & $F 2 R L 3$ & 0.002086929 & Co-expression \\
\hline$K R T 1$ & PARD3 & 0.008348665 & Co-expression \\
\hline$K R T 1$ & KRT2 & 0.001395255 & Co-expression \\
\hline SERPINF2 & PRSS2 & 0.020101048 & Co-expression \\
\hline PRSS3 & PRSS2 & 0.037385598 & Co-expression \\
\hline$K R T 2$ & $F 2 R L 1$ & 0.004147036 & Co-expression \\
\hline$K R T 2$ & PARD3 & 0.004057049 & Co-expression \\
\hline PRSS2 & SERPINB8 & 0.013921468 & Co-expression \\
\hline KRT1 & PARD3 & 0.007636325 & Co-expression \\
\hline KRT1 & $F 2 R L 3$ & 0.001890512 & Co-expression \\
\hline KRT1 & KRT2 & 0.000903638 & Co-expression \\
\hline SERPINF2 & $K R T 2$ & 0.001538189 & Co-expression \\
\hline$P R S S 3$ & SERPINB8 & 0.012880304 & Co-expression \\
\hline PRSS3 & PRSS2 & 0.01267024 & Co-expression \\
\hline PRSS3 & PRSS2 & 0.008046081 & Co-expression \\
\hline$A L B$ & SERPINF2 & 0.012912146 & Co-expression \\
\hline PRSS3 & PRSS2 & 0.059784386 & Co-expression \\
\hline$A B C A 4$ & PRSS1 & 0.021043219 & Co-expression \\
\hline PRSS2 & PRSS1 & 0.017638749 & Co-expression \\
\hline PRSS3 & PRSS1 & 0.010804671 & Co-expression \\
\hline PRSS3 & PRSS2 & 0.008761909 & Co-expression \\
\hline$A B C A 4$ & TMPRSS15 & 0.014334416 & Co-expression \\
\hline KRT10 & $K R T 2$ & 0.013258844 & Co-expression \\
\hline KRT1 & KRT2 & 0.012602167 & Co-expression \\
\hline$K R T 1$ & KRT10 & 0.010437634 & Co-expression \\
\hline PRSS3 & PRSS2 & 0.020688048 & Co-expression \\
\hline$A P P$ & $F 2 R$ & 0.007284051 & Co-expression \\
\hline$K R T 1$ & SERPINII & 0.011799906 & Co-expression \\
\hline PRSS3 & $K R T 2$ & 0.01028535 & Co-expression \\
\hline PRSS3 & PRSS2 & 0.056584958 & Co-expression \\
\hline SERPINB8 & $F 2 R L 1$ & 0.007467608 & Co-expression \\
\hline
\end{tabular}


Mustafa et al., Int. Ann. Sci.; Vol. 8, Issue 1, pp: 96-113, 2020

\begin{tabular}{|c|c|c|c|}
\hline PRSS2 & $F 2 R L 1$ & 0.009436603 & Co-expression \\
\hline PRSS3 & $F 2 R L 1$ & 0.0091086 & Co-expression \\
\hline PRSS3 & PRSS2 & 0.006767724 & Co-expression \\
\hline PRSS2 & SERPINB8 & 0.005437602 & Co-expression \\
\hline CEP 250 & $K R T 1$ & 0.007838975 & Co-expression \\
\hline$A L B$ & $A P P$ & 0.015414801 & Co-expression \\
\hline PRSS2 & $F 2 R L 1$ & 0.011420856 & Co-expression \\
\hline KRT10 & $K R T 2$ & 0.031353086 & Co-expression \\
\hline$K R T 1$ & SERPINB8 & 0.017290482 & Co-expression \\
\hline$K R T 1$ & $K R T 2$ & 0.030572487 & Co-expression \\
\hline$A L B$ & SERPINF2 & 0.011540175 & Co-localization \\
\hline$F 2 R$ & $F 2 R L 3$ & 0.004708032 & Co-localization \\
\hline PRSS2 & PRSS1 & 0.025921002 & Co-localization \\
\hline$K R T 1$ & KRT10 & 0.025425598 & Co-localization \\
\hline PRSS3 & PRSS1 & 0.023983192 & Co-localization \\
\hline PRSS3 & PRSS2 & 0.023682926 & Co-localization \\
\hline$A L B$ & SERPINF2 & 0.016614223 & Co-localization \\
\hline TMPRSS15 & PRSS1 & 0.02293591 & Co-localization \\
\hline TMPRSS15 & PRSS2 & 0.022705158 & Co-localization \\
\hline TMPRSS15 & $P R S S 3$ & 0.022577295 & Co-localization \\
\hline ONECUT2 & PRSS1 & 0.022678863 & Co-localization \\
\hline ONECUT2 & PRSS2 & 0.022438433 & Co-localization \\
\hline ONECUT2 & PRSS3 & 0.02270408 & Co-localization \\
\hline ONECUT2 & TMPRSS15 & 0.026521208 & Co-localization \\
\hline$F 2 R L 1$ & PRSS1 & 0.31954107 & Pathway \\
\hline PARD3 & PRSS1 & 0.15361263 & Pathway \\
\hline$F 2 R L 3$ & PRSS1 & 0.1483753 & Pathway \\
\hline$F 2 R$ & PRSSI & 0.12154161 & Pathway \\
\hline$F 2 R$ & $F 2 R L 3$ & 0.03525233 & Pathway \\
\hline PRSS2 & $F 2 R L 1$ & 0.31954107 & Pathway \\
\hline PRSS2 & PARD3 & 0.15361263 & Pathway \\
\hline PRSS2 & $F 2 R L 3$ & 0.1483753 & Pathway \\
\hline PRSS2 & $F 2 R$ & 0.12154161 & Pathway \\
\hline$F 2 R L 1$ & PRSS1 & 0.7365974 & Pathway \\
\hline CEP250 & PRSS1 & 0.08479679 & Physical Interactions \\
\hline CEP 250 & $D D X 5$ & 0.021656184 & Physical Interactions \\
\hline$A L B$ & PRSS1 & 0.0910383 & Physical Interactions \\
\hline$A L B$ & KRT10 & 0.0910383 & Physical Interactions \\
\hline$A L B$ & $K R T 1$ & 0.04481957 & Physical Interactions \\
\hline$A L B$ & PRSS3 & 0.0910383 & Physical Interactions \\
\hline$D D X 5$ & PRSS1 & 0.3375174 & Physical Interactions \\
\hline KRT10 & $K R T 2$ & 0.37723482 & Physical Interactions \\
\hline$K R T 1$ & $K R T 2$ & 0.38693836 & Physical Interactions \\
\hline$K R T 1$ & KRT10 & 0.20642798 & Physical Interactions \\
\hline$K R T 2$ & PRSS1 & 0.28754097 & Physical Interactions \\
\hline KRT10 & PRSS1 & 0.24892193 & Physical Interactions \\
\hline KRT10 & $K R T 2$ & 0.15666465 & Physical Interactions \\
\hline KRT1 & PRSS1 & 0.24077669 & Physical Interactions \\
\hline KRT1 & $K R T 2$ & 0.15153825 & Physical Interactions \\
\hline$K R T 1$ & KRT1O & 0.13118546 & Physical Interactions \\
\hline SERPINB8 & PRSS1 & 0.4951709 & Physical Interactions \\
\hline SERPINF2 & PRSS1 & 0.28534 & Physical Interactions \\
\hline
\end{tabular}


Novel Mutations within PRSS1 Gene that Could Potentially Cause Hereditary Pancreatitis: Using Bioinformatics Approach

\begin{tabular}{|c|c|c|c|}
\hline$A P P$ & PRSS1 & 0.41637108 & Physical Interactions \\
\hline PRSS3 & $A P P$ & 0.13214332 & Physical Interactions \\
\hline TMEM150B & PRSS1 & 0.6281027 & Physical Interactions \\
\hline$A L B$ & $A P P$ & 0.0232307 & Physical Interactions \\
\hline CEP250 & $A P P$ & 0.0232307 & Physical Interactions \\
\hline SERPINB8 & PRSS1 & 0.18267727 & Physical Interactions \\
\hline$A P P$ & PRSS2 & 0.030401716 & Physical Interactions \\
\hline SERPINF2 & PRSS1 & 0.0573582 & Physical Interactions \\
\hline PRSS3 & $A P P$ & 0.05769704 & Physical Interactions \\
\hline$F 2 R L 3$ & $F 2 R L 1$ & 0.5863869 & Predicted \\
\hline$F 2 R$ & $F 2 R L 1$ & 0.17300643 & Predicted \\
\hline$K R T 1$ & $K R T 2$ & 0.15433232 & Predicted \\
\hline SERPINII & PRSS1 & 1 & Predicted \\
\hline$F 2 R L 3$ & $F 2 R L 1$ & 0.09312839 & Shared protein domains \\
\hline$F 2 R$ & $F 2 R L 1$ & 0.09312839 & Shared protein domains \\
\hline$F 2 R$ & $F 2 R L 3$ & 0.09312839 & Shared protein domains \\
\hline SERPINB8 & SERPINII & 0.028828265 & Shared protein domains \\
\hline PRSS2 & PRSS1 & 0.008043572 & Shared protein domains \\
\hline KRT10 & $K R T 2$ & 0.008737453 & Shared protein domains \\
\hline KRT1 & $K R T 2$ & 0.024351321 & Shared protein domains \\
\hline SERPINF2 & SERPINII & 0.028828265 & Shared protein domains \\
\hline SERPINF2 & SERPINB8 & 0.028828265 & Shared protein domains \\
\hline PRSS3 & PRSS1 & 0.010362946 & Shared protein domains \\
\hline PRSS3 & PRSS2 & 0.010437737 & Shared protein domains \\
\hline TMPRSS15 & PRSS1 & 0.006456545 & Shared protein domains \\
\hline TMPRSS15 & PRSS2 & 0.006503143 & Shared protein domains \\
\hline$F 2 R L 3$ & $F 2 R L 1$ & 0.00354377 & Shared protein domains \\
\hline$F 2 R$ & $F 2 R L 1$ & 0.00354377 & Shared protein domains \\
\hline$F 2 R$ & $F 2 R L 3$ & 0.00354377 & Shared protein domains \\
\hline SERPINB8 & SERPINII & 0.027777778 & Shared protein domains \\
\hline PRSS2 & PRSS1 & 0.009871521 & Shared protein domains \\
\hline KRT10 & KRT2 & 0.010121632 & Shared protein domains \\
\hline$K R T 1$ & $K R T 2$ & 0.018882168 & Shared protein domains \\
\hline$K R T 1$ & KRT10 & 0.011125098 & Shared protein domains \\
\hline SERPINF2 & SERPINII & 0.027777778 & Shared protein domains \\
\hline SERPINF2 & SERPINB8 & 0.027777778 & Shared protein domains \\
\hline PRSS3 & PRSS1 & 0.009871521 & Shared protein domains \\
\hline PRSS3 & PRSS2 & 0.011186602 & Shared protein domains \\
\hline
\end{tabular}

Table 7: Maintenance outline of amino acids in PRSS1

\begin{tabular}{cccccc}
\hline $\begin{array}{c}\text { Residues } \\
\text { position }\end{array}$ & Residues & $\begin{array}{c}\text { CS Score } \\
\text { normalized }\end{array}$ & Color & Residues Variety & B/E \\
\hline 1 & $\mathrm{M}$ & 0.211 & 7.3 & $\mathrm{M}, \mathrm{N}, \mathrm{P}$ & $\mathrm{e}$ \\
4 & $\mathrm{~L}$ & 0.361 & 6.3 & $\mathrm{M}, \mathrm{S}, \mathrm{L}, \mathrm{I}, \mathrm{H}, \mathrm{F}$ & $\mathrm{b}$ \\
\hline
\end{tabular}

CS Score normalized (1-4= variable, $5=$ average, $6-9=$ conserved).

B/E: Buried (b) or Exposed (e) residue.

Table 8: Shows variants consequences, impact and biotype features by VEP tool

\begin{tabular}{cccccc}
\hline $\begin{array}{c}\text { Uploaded } \\
\text { variation }\end{array}$ & SNP & Location & Consequence & IMPACT & BIOTYPE \\
\hline rs1366278558 & M/R & $7: 142749486-142749486$ & start lost & HIGH & protein coding \\
rs1366278558 & - & $7: 142749486-142749486$ & $\begin{array}{c}\text { variant } \\
\text { non coding transcript } \\
\text { exon variant }\end{array}$ & MODIFIER & retained intron \\
rs1366278558 & - & $7: 142749486-142749486$ & retained intron \\
\hline
\end{tabular}


Mustafa et al., Int. Ann. Sci.; Vol. 8, Issue 1, pp: 96-113, 2020

\begin{tabular}{|c|c|c|c|c|c|}
\hline rs 1366278558 & $\mathrm{M} / \mathrm{R}$ & $7: 142749486-142749486$ & start lost & HIGH & protein coding \\
\hline rs 1366278558 & $\mathrm{M} / \mathrm{R}$ & 7:142749486-142749486 & $\begin{array}{l}\text { upstream gene } \\
\text { variant }\end{array}$ & MODIFIER & protein coding \\
\hline rs1366278558 & $\mathrm{M} / \mathrm{R}$ & $7: 142749486-142749486$ & $\begin{array}{l}\text { non coding transcript } \\
\text { exon variant }\end{array}$ & MODIFIER & retained intron \\
\hline rs1366278558 & $\mathrm{M} / \mathrm{R}$ & 7:142749486-142749486 & start lost & HIGH & protein coding \\
\hline rs 1366278558 & $\mathrm{M} / \mathrm{R}$ & $7: 142749486-142749486$ & $\begin{array}{c}\text { regulatory region } \\
\text { variant }\end{array}$ & MODIFIER & open chromatin region \\
\hline rs767036052 & $\mathrm{L} / \mathrm{P}$ & $7: 142749495-142749495$ & missense variant & MODERATE & protein coding \\
\hline rs767036052 & $\mathrm{L} / \mathrm{P}$ & $7: 142749495-142749495$ & $\begin{array}{l}\text { upstream gene } \\
\text { variant }\end{array}$ & MODIFIER & retained intron \\
\hline rs 767036052 & $\mathrm{~L} / \mathrm{P}$ & 7:142749495-142749495 & $\begin{array}{l}\text { non coding transcript } \\
\text { exon variant }\end{array}$ & MODIFIER & retained intron \\
\hline rs767036052 & $\mathrm{L} / \mathrm{P}$ & 7:142749495-142749495 & missense variant & MODERATE & protein coding \\
\hline rs767036052 & $\mathrm{L} / \mathrm{P}$ & $7: 142749495-142749495$ & $\begin{array}{l}\text { upstream gene } \\
\text { variant }\end{array}$ & MODIFIER & protein coding \\
\hline rs767036052 & $\mathrm{L} / \mathrm{P}$ & 7:142749495-142749495 & $\begin{array}{l}\text { non coding transcript } \\
\text { exon variant }\end{array}$ & MODIFIER & retained intron \\
\hline rs767036052 & $\mathrm{L} / \mathrm{P}$ & $7: 142749495-142749495$ & missense variant & MODERATE & protein coding \\
\hline rs767036052 & $\mathrm{L} / \mathrm{P}$ & 7:142749495-142749495 & $\begin{array}{c}\text { regulatory region } \\
\text { variant }\end{array}$ & MODIFIER & open chromatin region \\
\hline rs1366278558 & $\mathrm{M} / \mathrm{R}$ & $\begin{array}{c}\text { CHR_HSCHR7_2_CTG6:142790203- } \\
\text { 142790203 }\end{array}$ & start lost & HIGH & protein coding \\
\hline rs 1366278558 & $\mathrm{M} / \mathrm{R}$ & $\begin{array}{c}\text { CHR_HSCHR7_2_CTG6:142790203- } \\
\text { 142790203 }\end{array}$ & start lost & HIGH & protein coding \\
\hline rs 1366278558 & $\mathrm{M} / \mathrm{R}$ & $\begin{array}{c}\text { CHR_HSCHR7_2_CTG6:142790203- } \\
142790203\end{array}$ & $\begin{array}{l}\text { non coding transcript } \\
\text { exon variant }\end{array}$ & MODIFIER & retained intron \\
\hline rs 1366278558 & $\mathrm{M} / \mathrm{R}$ & $\begin{array}{c}\text { CHR_HSCHR7_2_CTG6:142790203- } \\
\text { 142790203 }\end{array}$ & $\begin{array}{l}\text { upstream gene } \\
\text { variant }\end{array}$ & MODIFIER & retained intron \\
\hline rs1366278558 & $\mathrm{M} / \mathrm{R}$ & $\begin{array}{c}\text { CHR_HSCHR7_2_CTG6:142790203- } \\
\text { 142790203 }\end{array}$ & $\begin{array}{l}\text { non coding transcript } \\
\text { exon variant }\end{array}$ & MODIFIER & retained intron \\
\hline rs1366278558 & $\mathrm{M} / \mathrm{R}$ & $\begin{array}{c}\text { CHR_HSCHR7_2_CTG6:142790203- } \\
142790203\end{array}$ & $\begin{array}{l}\text { upstream gene } \\
\text { variant }\end{array}$ & MODIFIER & protein coding \\
\hline rs1366278558 & $\mathrm{M} / \mathrm{R}$ & $\begin{array}{c}\text { CHR_HSCHR7_2_CTG6:142790203- } \\
\text { 142790203 }\end{array}$ & start lost & HIGH & protein coding \\
\hline rs767036052 & $\mathrm{L} / \mathrm{P}$ & $\begin{array}{c}\text { CHR_HSCHR7_2_CTG6:142790212- } \\
\text { 142790212 }\end{array}$ & missense variant & MODERATE & protein coding \\
\hline rs767036052 & $\mathrm{L} / \mathrm{P}$ & $\begin{array}{c}\text { CHR_HSCHR7_2_CTG6:142790212- } \\
\text { 142790212 }\end{array}$ & missense variant & MODERATE & protein coding \\
\hline rs 767036052 & $\mathrm{~L} / \mathrm{P}$ & $\begin{array}{c}\text { CHR_HSCHR7_2_CTG6:142790212- } \\
\text { 142790212 }\end{array}$ & $\begin{array}{l}\text { non coding transcript } \\
\text { exon variant }\end{array}$ & MODIFIER & retained intron \\
\hline rs 767036052 & $\mathrm{~L} / \mathrm{P}$ & $\begin{array}{c}\text { CHR_HSCHR7_2_CTG6:142790212- } \\
\text { 142790212 }\end{array}$ & $\begin{array}{l}\text { upstream gene } \\
\text { variant }\end{array}$ & MODIFIER & retained intron \\
\hline rs 767036052 & $\mathrm{~L} / \mathrm{P}$ & $\begin{array}{c}\text { CHR_HSCHR7_2_CTG6:142790212- } \\
\text { 142790212 }\end{array}$ & $\begin{array}{l}\text { non coding transcript } \\
\text { exon variant }\end{array}$ & MODIFIER & retained intron \\
\hline rs767036052 & $\mathrm{L} / \mathrm{P}$ & $\begin{array}{c}\text { CHR_HSCHR7_2_CTG6:142790212- } \\
\text { 142790212 }\end{array}$ & $\begin{array}{l}\text { upstream gene } \\
\text { variant }\end{array}$ & MODIFIER & protein coding \\
\hline rs767036052 & $\mathrm{L} / \mathrm{P}$ & $\begin{array}{c}\text { CHR_HSCHR7_2_CTG6:142790212- } \\
\text { 142790212 }\end{array}$ & missense variant & MODERATE & protein coding \\
\hline
\end{tabular}

The predicted variants consequences are shown in (Tables 8), VEP reported regulatory consequences for many variants, including 6 variants within a coding region, 2 variants within a non-coding region, 8 variants within upstream gene, 8 variants within noncoding transcript exon and 6 variant within start lost codon. in general any mutations within a coding region will likely affect the protein function, while regulatory variants within non-coding genomic regions can greatly affect the expression of protein $[67,68]$, the SNPs in the upstream, 5'UTR region might affect transcription or translation process [69] In the light of our work, we agree with previous studies linking (P36R and V123M) with chronic pancreatitis [70]. We also support the previous findings relating these mutations to certain forms of hereditary pancreatitis. (P36R and V123M) may be associated with pancreatic cancer along other types of cancer and it has also been related in the past to familial Peutz-Jeghers syndrome [72-75], so this study can be used as a platform to develop large scale studies in the future in relation 
to these disease. This study is the first computational analysis of PRSS1 gene which was based on functional and structural analysis while all earlier studies $[31,76]$ foxed on frequency and Whole exome sequencing. Furthermore, this study revealed two novel mutations (M1R, and L4P) that had a possible functional influence, which means that these SNPs could be used as diagnostic biomarkers for HP. Further wet lab studies are needed to confirm these results.

\section{Conclusion}

A total of two SNPs was predicted to have potential responsibility for the functional and structural alterations of PRSS1 gene. It is predicted from comparison of the results between various bioinformatics analysis tools; Out of a total of 911 SNPs in the PRSS1 gene, 506 were nsSNPs; out of 506 nsSNPs, two were found to be the most deleterious nsSNPs (M1R and L4P) by eight functional analysis tools. Stability analysis results showed a dramatic decrease of the protein stability. These two SNPs may assist as diagnostic biomarkers for the prognosis of HP and may be used as a platform to develop large-scale studies in the future.

\section{Declarations}

\subsection{Data Availability}

All data underlying the results are available as part of the article and no additional source data are required.

\subsection{Competing Interests}

The authors declare that there is no conflict of interest regarding the publication of this work.

\section{How to Cite this Article:}

M. Mustafa, A. Abdelmoneim, N. Elfadol, S. Osman, T. Abdelhameed, and M. Hassan, "Novel Mutations within PRSS1 Gene that Could Potentially Cause Hereditary Pancreatitis: Using Bioinformatics Approach", Int. Ann. Sci., vol. 8, no. 1, pp. 96-113, Nov. 2019. doi:10.21467/ias.8.1.96-113

\section{References}

[1] R. M. Charnley, "Hereditary pancreatitis," World J Gastroenterol, vol. 9, pp. 1-4, Jan 2003.

[2] W. D. Jackson, "Pancreatitis: etiology, diagnosis, and management," Curr Opin Pediatr, vol. 13, pp. 447-51, Oct 2001.
[3] L. N. Dai, Y. W. Chen, W. H. Yan, L. N. Lu, Y. J. Tao, and W. Cai, "Hereditary pancreatitis of 3 Chinese children: Case report and literature review," Medicine (Baltimore), vol. 95, p. e4604, Sep 2016.

[4] L. Le Bodic, J. D. Bignon, O. Raguenes, B. Mercier, T. Georgelin, M. Schnee, et al., "The hereditary pancreatitis gene maps to long arm of chromosome 7," Hum Mol Genet, vol. 5, pp. 549-54, Apr 1996.

[5] P. Dyrla, T. Nowak, J. Gil, C. Adamiec, M. Bobula, and M. Saracyn, "[Hereditary pancreatitis]," Pol Merkur Lekarski, vol. 40, pp. 113-6, Feb 2016.

[6] V. Rebours, P. Levy, and P. Ruszniewski, "An overview of hereditary pancreatitis," Dig Liver Dis, vol. 44, pp. 815, Jan 2012.

[7] N. Howes, M. M. Lerch, W. Greenhalf, D. D. Stocken, I. Ellis, P. Simon, et al., "Clinical and genetic characteristics of hereditary pancreatitis in Europe," Clin Gastroenterol Hepatol, vol. 2, pp. 252-61, Mar 2004.

[8] S. K. Lee, "[Hereditary pancreatitis]," Korean $J$ Gastroenterol, vol. 46, pp. 358-67, Nov 2005.

[9] K. L. Raphael and F. F. Willingham, "Hereditary pancreatitis: current perspectives," Clin Exp Gastroenterol, vol. 9, pp. 197-207, 2016.

[10] A. Masamune, K. Kikuta, S. Hamada, E. Nakano, K. Kume, A. Inui, et al., "Nationwide survey of hereditary pancreatitis in Japan," J Gastroenterol, vol. 53, pp. 152160, Jan 2018.

[11] J. Mora, L. Comas, E. Ripoll, P. Goncalves, J. M. Queralto, F. Gonzalez-Sastre, et al., "Genetic mutations in a Spanish population with chronic pancreatitis," Pancreatology, vol. 9, pp. 644-51, 2009.

[12] S. Raty, A. Piironen, M. Babu, H. Pelli, J. Sand, S. Uotila, et al., "Screening for human cationic trypsinogen (PRSS1) and trypsinogen inhibitor gene (SPINK1) mutations in a Finnish family with hereditary pancreatitis," Scand J Gastroenterol, vol. 42, pp. 10005, Aug 2007.

[13] J. R. Sibert, "Hereditary pancreatitis in England and Wales," J Med Genet, vol. 15, pp. 189-201, Jun 1978.

[14] H. Goebell, R. Ammann, and W. Creutzfeldt, "History of the European pancreatic club: the first 40 years 19652005. The development of the European pancreatic club as a scientific society," Pancreatology, vol. 5 Suppl 1, pp. 1-15, 2005.

[15] S. E. Applebaum-Shapiro, R. Finch, R. H. Pfutzer, L. A. Hepp, L. Gates, S. Amann, et al., "Hereditary pancreatitis in North America: the Pittsburgh-Midwest Multi-Center Pancreatic Study Group Study," Pancreatology, vol. 1, pp. 439-43, 2001.

[16] M. T. Joergensen, K. Brusgaard, D. G. Cruger, A. M. Gerdes, and O. B. Schaffalitzky de Muckadell, "Genetic, epidemiological, and clinical aspects of hereditary pancreatitis: a population-based cohort study in Denmark," Am J Gastroenterol, vol. 105, pp. 1876-83, Aug 2010.

[17] A. B. Atlas, S. R. Orenstein, and D. M. Orenstein, "Pancreatitis in young children with cystic fibrosis," $J$ Pediatr, vol. 120, pp. 756-9, May 1992.

[18] A. Masamune, "Genetics of pancreatitis: the 2014 update," Tohoku J Exp Med, vol. 232, pp. 69-77, Feb 2014.

[19] C. Langner, "[Hereditary gastric and pancreatic cancer]," Pathologe, vol. 38, pp. 164-169, May 2017.

[20] A. B. Lowenfels, P. Maisonneuve, E. P. DiMagno, Y. Elitsur, L. K. Gates, Jr., J. Perrault, et al., "Hereditary pancreatitis and the risk of pancreatic cancer. 
International Hereditary Pancreatitis Study Group," $J$ Natl Cancer Inst, vol. 89, pp. 442-6, Mar 191997.

[21] D. Malka, P. Hammel, F. Maire, P. Rufat, I. Madeira, F. Pessione, et al., "Risk of pancreatic adenocarcinoma in chronic pancreatitis," Gut, vol. 51, pp. 849-52, Dec 2002.

[22] F. U. Weiss, "Pancreatic cancer risk in hereditary pancreatitis," Front Physiol, vol. 5, p. 70, 2014.

[23] A. B. Lowenfels, P. Maisonneuve, D. C. Whitcomb, M. M. Lerch, and E. P. DiMagno, "Cigarette smoking as a risk factor for pancreatic cancer in patients with hereditary pancreatitis," Jama, vol. 286, pp. 169-70, Jul 112001.

[24] A. B. Lowenfels, P. Maisonneuve, and D. C. Whitcomb, "Risk factors for cancer in hereditary pancreatitis. International Hereditary Pancreatitis Study Group," Med Clin North Am, vol. 84, pp. 565-73, May 2000.

[25] A. Mastoraki, A. Tzortzopoulou, S. Tsela, N. Danias, G. Sakorafas, V. Smyrniotis, et al., "Hereditary pancreatitis: dilemmas in differential diagnosis and therapeutic approach," J Gastrointest Cancer, vol. 45, pp. 22-6, Mar 2014.

[26] M. R. Patel, A. L. Eppolito, and F. F. Willingham, "Hereditary pancreatitis for the endoscopist," Therap Adv Gastroenterol, vol. 6, pp. 169-79, Mar 2013.

[27] S. Kargl, M. Kienbauer, H. C. Duba, R. Schofl, and W. Pumberger, "Therapeutic step-up strategy for management of hereditary pancreatitis in children," $J$ Pediatr Surg, vol. 50, pp. 511-4, Apr 2015.

[28] J. LaRusch, S. Solomon, and D. C. Whitcomb, "Pancreatitis Overview," in GeneReviews $((R))$, M. P. Adam, H. H. Ardinger, R. A. Pagon, S. E. Wallace, L. J. H. Bean, K. Stephens, et al., Eds., ed Seattle (WA): University of Washington, Seattle

University of Washington, Seattle. GeneReviews is a registered trademark of the University of Washington, Seattle. All rights reserved., 1993.

[29] E. D. Rivera Rivera, "[Pancreatitis, genes and islet cells auto transplant; updates and new horizons]," Rev Gastroenterol Peru, vol. 37, pp. 156-161, Apr-Jun 2017.

[30] S. Solomon, D. C. Whitcomb, and J. LaRusch, "PRSS1Related Hereditary Pancreatitis," in GeneReviews $((R))$, M. P. Adam, H. H. Ardinger, R. A. Pagon, S. E. Wallace, L. J. H. Bean, K. Stephens, et al., Eds., ed Seattle (WA): University of Washington, Seattle

University of Washington, Seattle. GeneReviews is a registered trademark of the University of Washington, Seattle. All rights reserved., 1993.

[31] J. LaRusch, M. M. Barmada, S. Solomon, and D. C. Whitcomb, "Whole exome sequencing identifies multiple, complex etiologies in an idiopathic hereditary pancreatitis kindred," Jop, vol. 13, pp. 258-62, May 10 2012.

[32] J. Y. Kim, S. H. Choi, J. S. Ihm, S. J. Kim, I. J. Kim, and C. M. Kim, "[A case of R122H mutation of cationic trypsinogen gene in a pediatric patient with hereditary pancreatitis complicated by pseudocyst and hemosuccus pancreaticus]," Korean J Gastroenterol, vol. 45, pp. 1306, Feb 2005.

[33] T. Jamer and B. Iwanczak, "[Genetic mutations as a cause of acute recurrent pancreatitis in children - case report and literature review]," Dev Period Med, vol. 20, pp. 228-234, 2016.

[34] A. Lal and D. R. Lal, "Hereditary pancreatitis," Pediatr Surg Int, vol. 26, pp. 1193-9, Dec 2010.

[35] C. Le Marechal, E. Masson, J. M. Chen, F. Morel, P. Ruszniewski, P. Levy, et al., "Hereditary pancreatitis caused by triplication of the trypsinogen locus," Nat Genet, vol. 38, pp. 1372-4, Dec 2006.

[36] P. Simon, F. U. Weiss, M. Sahin-Toth, M. Parry, O. Nayler, B. Lenfers, et al., "Hereditary pancreatitis caused by a novel PRSS1 mutation (Arg-122 --> Cys) that alters autoactivation and autodegradation of cationic trypsinogen," J Biol Chem, vol. 277, pp. 5404-10, Feb 15 2002.

[37] B. C. Nemeth and M. Sahin-Toth, "Human cationic trypsinogen (PRSS1) variants and chronic pancreatitis," Am J Physiol Gastrointest Liver Physiol, vol. 306, pp. G466-73, Mar 2014.

[38] J. M. Chen, C. Le Marechal, D. Lucas, O. Raguenes, and C. Ferec, "'Loss of function" mutations in the cationic trypsinogen gene (PRSS1) may act as a protective factor against pancreatitis," Mol Genet Metab, vol. 79, pp. 6770, May 2003.

[39] D. C. Whitcomb, M. C. Gorry, R. A. Preston, W. Furey, M. J. Sossenheimer, C. D. Ulrich, et al., "Hereditary pancreatitis is caused by a mutation in the cationic trypsinogen gene," Nat Genet, vol. 14, pp. 141-5, Oct 1996.

[40] T. Y. Lee, H. C. Oh, M. H. Kim, S. Kwon, S. S. Lee, D. W. Seo, et al., "[Three cases of hereditary pancreatitis in two households in the same family associated with $\mathrm{R} 122 \mathrm{H}$ mutation in cationic trypsinogen gene]," Korean J Gastroenterol, vol. 49, pp. 395-9, Jun 2007.

[41] C. Hanck, A. Schneider, and D. C. Whitcomb, "Genetic polymorphisms in alcoholic pancreatitis," Best Pract Res Clin Gastroenterol, vol. 17, pp. 613-23, Aug 2003.

[42] M. I. Mustafa, T. A. Abdelhameed, F. A. Abdelrhman, S. A. Osman, and M. A. Hassan, "Novel Deleterious nsSNPs within MEFV Gene that Could Be Used as Diagnostic Markers to Predict Hereditary Familial Mediterranean Fever: Using Bioinformatics Analysis," Adv Bioinformatics, vol. 2019, p. 1651587, 2019.

[43] Z. Kosaloglu, J. Bitzer, N. Halama, Z. Huang, M. Zapatka, A. Schneeweiss, et al., "In silico SNP analysis of the breast cancer antigen NY-BR-1," BMC Cancer, vol. 16, p. 901, Nov 182016.

[44] Y. H. Bakhit, M. O. Ibrahim, M. Amin, Y. A. Mirghani, and M. A. Hassan, "In Silico Analysis of SNPs in PARK2 and PINK1 Genes That Potentially Cause Autosomal Recessive Parkinson Disease," $A d v$ Bioinformatics, vol. 2016, p. 9313746, 2016.

[45] D. A. Benson, I. Karsch-Mizrachi, K. Clark, D. J. Lipman, J. Ostell, and E. W. Sayers, "GenBank," Nucleic Acids Res, vol. 40, pp. D48-53, Jan 2012.

[46] "UniProt: the universal protein knowledgebase," Nucleic Acids Res, vol. 45, pp. D158-d169, Jan 42017.

[47] N. L. Sim, P. Kumar, J. Hu, S. Henikoff, G. Schneider, and P. C. Ng, "SIFT web server: predicting effects of amino acid substitutions on proteins," Nucleic Acids Res, vol. 40, pp. W452-7, Jul 2012.

[48] SIFT server. Available: https://sift.bii.a-star.edu.sg/

[49] E. Capriotti and R. B. Altman, "Improving the prediction of disease-related variants using protein threedimensional structure," BMC Bioinformatics, vol. 12 Suppl 4, p. S3, 2011.

[50] PolyPhen-2 server. Available: http://genetics.bwh.harvard.edu/pph2/

[51] Y. Choi, G. E. Sims, S. Murphy, J. R. Miller, and A. P. Chan, "Predicting the functional effect of amino acid substitutions and indels," PLoS One, vol. 7, p. e46688, 2012. 
[52] M. Hecht, Y. Bromberg, and B. Rost, "Better prediction of functional effects for sequence variants," $B M C$ Genomics, vol. 16 Suppl 8, p. S1, 2015.

[53] R. Calabrese, E. Capriotti, P. Fariselli, P. L. Martelli, and R. Casadio, "Functional annotations improve the predictive score of human disease-related mutations in proteins," Hum Mutat, vol. 30, pp. 1237-44, Aug 2009.

[54] V. Lopez-Ferrando, A. Gazzo, X. de la Cruz, M. Orozco, and J. L. Gelpi, "PMut: a web-based tool for the annotation of pathological variants on proteins, 2017 update," Nucleic Acids Res, vol. 45, pp. W222-w228, Jul 32017.

[55] E. Capriotti, P. Fariselli, and R. Casadio, "I-Mutant2.0: predicting stability changes upon mutation from the protein sequence or structure," Nucleic Acids Res, vol. 33, pp. W306-10, Jul 12005.

[56] J. Cheng, A. Randall, and P. Baldi, "Prediction of protein stability changes for single-site mutations using support vector machines," Proteins, vol. 62, pp. 1125-32, Mar 1 2006.

[57] H. Ashkenazy, E. Erez, E. Martz, T. Pupko, and N. BenTal, "ConSurf 2010: calculating evolutionary conservation in sequence and structure of proteins and nucleic acids," Nucleic Acids Res, vol. 38, pp. W529-33, Jul 2010.

[58] H. Ashkenazy, S. Abadi, E. Martz, O. Chay, I. Mayrose, T. Pupko, et al., "ConSurf 2016: an improved methodology to estimate and visualize evolutionary conservation in macromolecules," Nucleic Acids Res, vol. 44, pp. W344-50, Jul 82016.

[59] O. O. Oni, A. A. Owoade, and C. A. O. Adeyefa, "Design and evaluation of primer pairs for efficient detection of avian rotavirus," Trop Anim Health Prod, vol. 50, pp. 267-273, Feb 2018.

[60] D. Warde-Farley, S. L. Donaldson, O. Comes, K. Zuberi, R. Badrawi, P. Chao, et al., "The GeneMANIA prediction server: biological network integration for gene prioritization and predicting gene function," Nucleic Acids Res, vol. 38, pp. W214-20, Jul 2010.

[61] M. J. Meyer, R. Lapcevic, A. E. Romero, M. Yoon, J. Das, J. F. Beltran, et al., "mutation3D: Cancer Gene Prediction Through Atomic Clustering of Coding Variants in the Structural Proteome," Hum Mutat, vol. 37, pp. 447-56, May 2016.

[62] project HOPE server. Available: http://www.cmbi.ru.nl/hope

[63] E. F. Pettersen, T. D. Goddard, C. C. Huang, G. S. Couch, D. M. Greenblatt, E. C. Meng, et al., "UCSF Chimera--a visualization system for exploratory research and analysis," J Comput Chem, vol. 25, pp. 1605-12, Oct 2004.

[64] W. McLaren, L. Gil, S. E. Hunt, H. S. Riat, G. R. Ritchie, A. Thormann, et al., "The Ensembl Variant Effect Predictor," Genome Biol, vol. 17, p. 122, Jun 62016.

[65] C. George Priya Doss, C. Sudandiradoss, R. Rajasekaran, P. Choudhury, P. Sinha, P. Hota, et al., "Applications of computational algorithm tools to identify functional SNPs," Funct Integr Genomics, vol. 8, pp. 309-16, Nov 2008.

[66] G. Chandrasekaran, E. C. Hwang, T. W. Kang, D. D. Kwon, K. Park, J. J. Lee, et al., "In silico analysis of the deleterious nsSNPs (missense) in the homeobox domain of human HOXB13 gene responsible for hereditary prostate cancer," vol. 90, pp. 188-199, Aug 2017.
[67] E. Rojano, P. Seoane, J. A. G. Ranea, and J. R. Perkins, "Regulatory variants: from detection to predicting impact," Brief Bioinform, Jun 82018.

[68] S. Dhamija and M. B. Menon, "Non-coding transcript variants of protein-coding genes - what are they good for?," RNA Biol, vol. 15, pp. 1025-1031, 2018.

[69] T. V. Tatarinova, E. Chekalin, Y. Nikolsky, S. Bruskin, D. Chebotarov, K. L. McNally, et al., "Nucleotide diversity analysis highlights functionally important genomic regions," Sci Rep, vol. 6, p. 35730, Oct 242016.

[70] A. Schnur, S. Beer, H. Witt, P. Hegyi, and M. SahinToth, "Functional effects of 13 rare PRSS1 variants presumed to cause chronic pancreatitis," Gut, vol. 63, pp. 337-43, Feb 2014.

[71] J. M. Chen, A. Piepoli Bis, L. Le Bodic, P. Ruszniewski, M. Robaszkiewicz, P. H. Deprez, et al., "Mutational screening of the cationic trypsinogen gene in a large cohort of subjects with idiopathic chronic pancreatitis," Clin Genet, vol. 59, pp. 189-93, Mar 2001.

[72] S. Hansford, P. Kaurah, H. Li-Chang, M. Woo, J. Senz, H. Pinheiro, et al., "Hereditary Diffuse Gastric Cancer Syndrome: CDH1 Mutations and Beyond," JAMA Oncol, vol. 1, pp. 23-32, Apr 2015.

[73] A. W. Kurian, E. E. Hare, M. A. Mills, K. E. Kingham, L. McPherson, A. S. Whittemore, et al., "Clinical evaluation of a multiple-gene sequencing panel for hereditary cancer risk assessment," J Clin Oncol, vol. 32, pp. 2001-9, Jul 12014

[74] L. Wang, J. Huang, M. Jiang, and X. Zheng, "AFP computational secreted network construction and analysis between human hepatocellular carcinoma (HCC) and no-tumor hepatitis/cirrhotic liver tissues," Tumour Biol, vol. 31, pp. 417-25, Oct 2010.

[75] R. H. Hruban, M. I. Canto, and C. J. Yeo, "Prevention of pancreatic cancer and strategies for management of familial pancreatic cancer," Dig Dis, vol. 19, pp. 76-84, 2001.

[76] F. U. Weiss, M. Zenker, A. B. Ekici, P. Simon, J. Mayerle, and M. M. Lerch, "Local clustering of PRSS1 $\mathrm{R} 122 \mathrm{H}$ mutations in hereditary pancreatitis patients from Northern Germany," Am J Gastroenterol, vol. 103, pp. 2585-8, Oct 2008 .

\section{Publish your books with AIJR publisher- \\ $\checkmark \quad$ Publish with ISBN and DOI. \\ $\checkmark \quad$ Publish Thesis/Dissertation as Monograph. \\ $\checkmark \quad$ Publish Book Monograph. \\ $\checkmark \quad$ Publish Edited Volume/ Book. \\ $\checkmark \quad$ Publish Conference Proceedings \\ $\checkmark \quad$ Retain full copyright of your books. \\ Submit your manuscript at books.aijr.org}

\section{Publish your research article in AIJR journals- $\checkmark \quad$ Online Submission and Tracking \\ $\checkmark$ Peer-Reviewed \\ $\checkmark \quad$ Rapid decision \\ $\checkmark \quad$ Immediate Publication after acceptance \\ $\checkmark \quad$ Articles freely available online \\ $\checkmark \quad$ Retain full copyright of your article.}

Submit your article at journals.aijr.in 